\title{
Biotechnology for Gas-to-Liquid (GTL) Wastewater Treatment: A Review
}

\author{
Riham Surkatti ${ }^{1,2}$, Muftah H. El-Naas ${ }^{1, *(\mathbb{D})}$, Mark C. M. Van Loosdrecht ${ }^{2}(\mathbb{D}$, \\ Abdelbaki Benamor ${ }^{1}{ }^{\mathbb{D}}$, Fatima Al-Naemi ${ }^{3}$ and Udeogu Onwusogh ${ }^{4}$ \\ 1 Gas Processing Center, Qatar University, Doha 2713, Qatar; riham.abubakr@qu.edu.qa (R.S.); \\ benamor.abdelbaki@qu.edu.qa (A.B.) \\ 2 Department of Biotechnology, Delft University of Technology, NL 2628 BC Delft, The Netherlands; \\ M.C.M.vanLoosdrecht@tudelft.nl \\ 3 Department of Biology, Qatar University, Doha 2713, Qatar; f.naemi@qu.edu.qa \\ 4 Qatar Shell RTC, Doha 3747, Qatar; Udeogu.Onwusogh@shell.com \\ * Correspondence: muftah@qu.edu.qa
}

Received: 8 June 2020; Accepted: 18 July 2020; Published: 27 July 2020

\begin{abstract}
Gas-to-liquid (GTL) technology involves the conversion of natural gas into several liquid hydrocarbon products. The Fischer-Tropsch (F-T) process is the most widely applied approach for GTL, and it is the main source of wastewater in the GTL process. The wastewater is generally characterized by high chemical oxygen demand (COD) and total organic carbon (TOC) content due to the presence of alcohol, ketones and organic acids. The discharge of this highly contaminated wastewater without prior treatment can cause adverse effects on human life and aquatic systems. This review examines aerobic and anaerobic biological treatment methods that have been shown to reduce the concentration of COD and organic compounds in wastewater. Advanced biological treatment methods, such as cell immobilization and application of nanotechnology are also evaluated. The removal of alcohol and volatile fatty acids (VFA) from GTL wastewater can be achieved successfully under anaerobic conditions. However, the combination of anaerobic systems with aerobic biodegradation processes or chemical treatment processes can be a viable technology for the treatment of highly contaminated GTL wastewater with high COD concentration. The ultimate goal is to have treated wastewater that has good enough quality to be reused in the GTL process, which could lead to cost reduction and environmental benefits.
\end{abstract}

Keywords: nanoparticles; Fischer-Tropsch (F-T) process; biological treatment; biomass immobilization

\section{Introduction}

Considerable amounts of wastewater are often released to the environment worldwide from industrial activities including oil refining, coal conversion, pharmaceutical and petrochemical industries, as well as coke and oil mill industries [1-3]. This wastewater usually contains different organic and inorganic pollutants including dissolved and suspended solids. The discharge of such wastewater into water bodies can cause serious problems to human health and the environment. Therefore, wastewater must be sufficiently treated to meet the discharge limit. Several physical and chemical methods were developed to reduce the concentration of phenols, COD, TOC and heavy metals in wastewater streams [4,5]. However, these methods are often costly due to the cost of chemicals, chemical sludge production and equipment. Biological methods are favorable in the area of wastewater treatment, due to their simplicity, low cost and environmental friendliness.

Biological treatments usually utilize microorganisms, such as yeast, bacteria, fungi and microalgae to reduce the concentration of organic compounds under aerobic or anaerobic conditions $[6,7]$. 
Several reactor schemes have been developed to operate in suspended growth, attached growth and hybrid systems. These systems are applied in batch reactors, membrane systems, fluidized beds and activated sludge systems [4-6]. The selection between the various biological processes is based on cost, land availability, operation simplicity and discharge limit of the pollutant. In industrial operation, biomass immobilization as biofilms is known as an efficient method to overcome the incorporation of free cells in wastewater treatment [8]. It offers several advantages including high removal efficiency, protecting the biomass from harsh environmental conditions and the possibility to reuse the microorganism and scale up of the process [9-11]. The use of nanoparticles to reinforce biomass immobilization matrices offers new bio-carriers that have increased strength and durability, and also has higher mechanical stability after long operation periods [12]. Several nanoparticles such as iron oxide $\left(\mathrm{Fe}_{2} \mathrm{O}_{3}\right)$, gold $(\mathrm{Au})$ and platinum $(\mathrm{Pt})$, were investigated [13]. Among them, $\mathrm{Fe}_{3} \mathrm{O}_{4}$ nanoparticles were widely applied for enzymes immobilization [14].

The natural Gas-to-liquid (GTL) process has gained special attention due to several advantages [15]. In GTL processes, the Fischer-Tropsch (F-T) synthesis is the major step, which results in the production of large amounts of wastewater [16]. This wastewater is characterized by a high dissolved hydrocarbon content, COD and TOC content, thus proper treatment should be applied before discharge of this wastewater into the water body [17]. Although anaerobic biological treatment has been commonly applied for F-T wastewater treatment, incomplete mineralization of some pollutants, such as butyric acid and propionic acid, can be the major limitation of this treatment method [18]. Therefore, there is still a challenge to develop anaerobic biological methods and/or to find new advanced methods to overcome these drawbacks.

This paper offers a comprehensive review of biological treatment of wastewater, highlighting recent publications in the literature about aerobic and anaerobic biological reactors and processes. It also outlines the improvement of biological treatment using advanced methods such as cell immobilization and the application of nano-biotechnology in the treatment systems. The review gives special attention to GTL wastewater production, characterization and conventional biological treatment methods applied to reduce the concentration of several contaminants. Finally, the review identifies research gaps in the area of GTL wastewater treatment and proposes new aspects for potential future research in the area.

\section{Biological Treatment of Industrial Wastewater}

\subsection{Main Industrial Wastewaters Composition}

Most industries including pulp and paper, coal plants, olive mills, oil refineries, chemical plants and petrochemical operations generate significant amounts of wastewaters $[3,18,19]$. The characterization of industrial wastewater streams differs within and among industries [2,3]. Industrial wastewaters vary in volume, flow, strength and composition, according to the specific manufacturing process and the water usage in each industry. In addition, the environmental impact of industrial wastewater depends on several characteristics including chemical oxygen demand (COD), biochemical oxygen demand (BOD), amount of suspended and dissolved solids, and also on organic and inorganic contents [20]. Table 1 shows the concentrations of major pollutants in examples of industrial wastewater effluents.

The COD content in most industrial effluents varies according to the type of wastewater. Some industrial wastewater such as GTL, olive oil mill and palm oil mill have high COD content that may reach up to $125,000 \mathrm{mg} / \mathrm{L}$ [23]. Additionally, they may contain contaminants that resist biological degradation, or other toxic components such as phenol and its derivatives, which have an adverse effect on the human body and aquatic systems. Phenols are highly distributed in refinery wastewaters, coal gasification and coke processes; the concentration of phenols may reach up to 12,800 in oil mill industries [20]. In addition, some industrial wastewaters contain small amounts of metals, nitrates and sulphates. Heavy metals are highly soluble in water, and can accumulate in human bodies and therefore cause serious health disorders [4]. The presence of ammonium in water bodies can also be 
a potential hazard to animals and humans and can affect water quality [26]. Moreover, high sulfate concentrations may lead to the release of sulfides which may damage the environment through odor and corrosion [27]. The specifications of GTL processes are often different from those of other wastewater streams, containing dissolved hydrocarbons that cannot be directly reused within the plant or discharged into the environment. Non-acid oxygenated (NAO) hydrocarbons, including alcohols, ketones, aldehydes, esters and ethers are the major contaminants in GTL-processed water. The water created in the GTL process is highly acidic and has high COD (up to $32 \mathrm{~g} / \mathrm{L}$ ) due to the presence of dissolved organic acids and alcohols [28]. Wastewaters containing such pollutants should be treated before discharge into the environment. Generally, conventional wastewater treatment methods applied for wastewater treatment are categorized as chemical, physical and biological treatment methods [29]. Pollutant removal using physio-chemical processes, such as adsorption [19], chemical oxidation [30], ion exchange [31], electrocoagulation [32] and Fenton processes [33], possesses serious drawbacks including formation of hazardous byproducts and high operation cost [34]. Biological methods are preferable since they are simple, inexpensive, environmental friendly and lead to the complete mineralization of toxic compounds [35].

Table 1. The concentrations of major pollutants in different types of industrial wastewater.

\begin{tabular}{|c|c|c|c|c|c|c|c|c|c|}
\hline Wastewater & $\mathrm{pH}$ & $\begin{array}{c}\text { TDS } \\
(\mathrm{mg} / \mathrm{L})\end{array}$ & $\begin{array}{c}\text { TSS } \\
(\mathrm{mg} / \mathrm{L})\end{array}$ & $\begin{array}{c}\text { Phenols } \\
\text { (mg/L) }\end{array}$ & $\begin{array}{c}\text { COD } \\
(\mathrm{mg} / \mathrm{L})\end{array}$ & $\begin{array}{c}\text { BOD } \\
(\mathrm{mg} / \mathrm{L})\end{array}$ & $\begin{array}{c}\text { Nitrates } \\
(\mathrm{mg} / \mathrm{L})\end{array}$ & $\begin{array}{c}\mathrm{OC} \\
(\mathrm{mg} / \mathrm{L})\end{array}$ & Ref. \\
\hline $\begin{array}{l}\text { Gas to liquid } \\
\text { (GTL) }\end{array}$ & 3 & - & - & - & $28,910.6-31,230.8$ & $118,533-13,116.9$ & - & 9540.5 & [17] \\
\hline Refinery & $8.3-8.7$ & $3800-6200$ & $30-40$ & - & $3970-4745$ & - & 28 & - & [21] \\
\hline $\begin{array}{c}\text { Coal } \\
\text { gasification }\end{array}$ & $7.6 \pm 0.3$ & 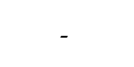 & - & $545 \pm 61$ & $2723 \pm 280$ & $805 \pm 96$ & 109 & - & [22] \\
\hline Textile & 9.44 & - & - & - & $850-1065$ & $200-300$ & & $240-410$ & [23] \\
\hline Olive oil mill & 5.2 & & & 12,800 & 124,000 & - & - & - & [24] \\
\hline Palm oil mill & $3.5 \pm 0.1$ & & & & 55,775 & 25,545 & 711 & - & [25] \\
\hline
\end{tabular}

\subsection{Biological Treatment}

Biological treatment has been widely applied in the area of water and wastewater treatment, presenting a highly efficient alternative in reducing the concentration of phenols, COD, TOC, heavy metals and oil traces from wastewater [16-18]. Biological treatment systems are generally classified into three different categories: suspended growth systems, supportive or attached growth and hybrid systems. In suspended growth systems, microorganisms are maintained in suspension mode within the liquid in batch reactors under aerobic or anaerobic conditions [36]. In contrast, the attached growth process is formed by granulation of activated sludge or attachment of the biomass as biofilms [36,37]. This technique has a greater concentration of biomass within the biological system and is applied in fluidized bed bioreactor (FBB), granular sludge reactors, packed bed reactor (PBR), spouted bed bioreactor (SBBR), rotating biological contactor (RBC) and biological activated filters $[20,21,24,36]$. The application of an attached growth system introduces a surface that is necessary for biofilm structure development. This biofilm, however, can achieve higher biomass concentration, and the microorganisms can stay in the reactor for unlimited time, resulting in better environmental conditions [9]. Hybrid systems are based on the combination of suspended and attached growth systems in the same reactor, such as the combination of activated sludge with fixed bed biofilters and submerged membrane bioreactors [21,22].

In biological wastewater treatment, several microorganisms are widely applied, such as bacteria, yeast, fungi and algae [38,39]. These microorganisms may degrade organic compounds to form carbon dioxide under aerobic conditions, or to produce biogas which is a mixture of $\mathrm{CO}_{2}$ and $\mathrm{CH}_{4}$, under anaerobic conditions [40]. Biological techniques shown high efficiency in wastewater treatment, particularly in the reduction of organics including phenols, COD and oil and grace [25,26]. However, cost, energy required, odor and sludge production vary according to the application of aerobic or 
anaerobic treatment. Generally, an aerobic condition can be applied as a stand-up wastewater treatment unit, while anaerobic conditions are mostly applied in a pretreatment unit. Aerobic degradation has several advantages over anaerobic treatment, including high removal efficiency, low start up time, low odors production and excellent effluent quality. In contrast the anaerobic treatment is favorable in certain types of wastewater treatment, since it produces bioenergy in addition to low nutrients requirements and low sludge production [41].

\subsubsection{Aerobic Biological Treatment}

Aerobic microorganisms have high efficiency in wastewater treatment, particularly for effluents contaminated with organic compounds. They are also more preferable than anaerobic microorganisms, since they grow faster and complete the transformation of the organic pollutants to inorganic compounds $\left(\mathrm{CO}_{2}, \mathrm{H}_{2} \mathrm{O}\right)$ [41]. Among aerobic systems, activated sludge is the most widely used; in this process the suspended bacterial biomass (the activated sludge) is responsible for the oxidation of pollutants present in wastewater [42]. An activated sludge system has been widely applied in the treatment of pharmaceutical, coke, refineries and olive mill wastewater treatment $[19,28]$. Activated sludge has shown high performance in the reduction of phenols, COD, BOD and hydrocarbons (Table 2). The activated sludge system has been applied for the degradation of phenols at concentration up to $800 \mathrm{mg} / \mathrm{L}$, and achieved around 98\% removal [43]. In contrast, COD reduction reached up to $89 \%$ in the petrochemical wastewater using activated sludge at initial concentration of $900 \mathrm{mg} / \mathrm{L}$ [44]. It was reported by Shokrollahzadeh et al. [44] that a bacterial mix consisting of sixty-seven species of activated sludge system isolated and identified mainly as Pseudomonas, Acidovorax, Sphingomonas, Comamonas, Flavobacterium, Cytophaga and Acinetobacter genera, was used in the treatment of pharmaceutical influent by activated sludge system and achieved reduction percentage of total hydrocarbons, ethylene dichloride, COD and vinyl chloride of $80 \%, 99 \%, 89 \%$ and $92 \%$, respectively [44].

Over the past few years, the development of aerobic biodegradation systems using pure culture and co-culture was investigated by a number of researchers, by applying a well-known identified bacteria, yeasts fungi and microalgae [17,30]. Several aerobic bacteria are able to utilize the organic compounds in wastewater as a sole source of carbon and energy $[45,46]$. Pseudomonas strains, especially Pseudomonas putida, have been widely studied in biological treatment of industrial wastewater. Although Pseudomonas putida has not been utilized for the degradation of organic compounds, such as alcohols, that are mainly present in GTL wastewater, it has been reported to be effective in the degradation of other organic contaminants, such as phenols, catechol and TCE in free and immobilized forms and showed high removal efficiencies [11,47-51]. Additionally, two strains named Pseudomonas aeruginosa and Pseudomonas pseudomallei, isolated from the pharmaceutical industry, were used for the reduction of COD and BOD from wastewater and showed high performance in the degradation of organic carbons [52]. Bacillus sp. is another aerobic bacterial strain that showed high performance in the biodegradation of toxic compounds in wastewater [53]. Many studies reported the use of Bacillus sp. in the textile and dye wastewater treatment [37]. Banerjee et al. [54] investigated the refinery wastewater treatment using immobilized Bacillus cereus. Immobilized bacteria efficiently reduce the content of phenols, COD, TOC, total ammonium-nitrogen and phosphate-phosphorus. Recently, Mahdavianpour et al. [55] tested a microbial mix that consisted of Bacillus megaterium, Bacillus aryabhattai, and Bacillus cereus for the removal of p-cresol, COD and nitrite. Results indicated that the presence of the Bacillus sp. in the mixed culture was the main cause of achieving high COD reduction and p-cresol biodegradation rate. Recently, Qia et al. [56], studied the application of pure cultures of bacteria (Stenotrophomonas acidaminiphila and Chryseobacterium scophthalmus) for the degradation of short chain organic compounds including ethanol, butanol and acetic acid. Acetic acid was completely removed by both strains within $24 \mathrm{~h}$; however, the removal efficiencies of butanol were $96.3 \%$ and $93.4 \%$ for S. acidaminiphila and C. scophthalmus, respectively. In addition, both strains removed up to $75 \%$ ethanol and they were unable to reduce the concentration of butyric acid from the wastewater. 
Yeasts have many advantages when compared to fungi and bacteria. They have the ability to grow fast like bacteria, and they can resist unfavorable environmental conditions like filamentous fungi. Several reports have described the ability of yeast species such as Candida tropicalis [46], Candida rugose, Candida cylindracea [57], and Trichosporon cutaneum [58], in the degradation of aromatic and aliphatic hydrocarbons. Yeasts showed high performance in olive mill wastewater treatment, which is usually characterized by its high COD concentration and the presence of phenolic compounds. As shown in Table 2, several yeast strains are capable of degrading COD at concentrations ranging from 100,000 to $200,000 \mathrm{mg} / \mathrm{L}$ in real olive mill wastewater. Cultures of Candida rugosa, Candida cylindracea and Yarrowia lipolytica were tested to grow in the olive mill wastewater. All strains were able to degrade phenols and COD. However, the highest removal percentage of phenolic compounds and COD resulted from the use of C.cylindracea [57]. Chtourou et al. [58] investigated the ability of Trichosporon cutaneum to degrade of phenols. The isolated yeast reduced phenolic content, which resulted from the reduction in alkyl phenols and in simple monomeric phenols. Additionally, more than $80 \%$ reduction of COD from wastewater was noticed by the isolated yeast in a period of 8 days. It should be mentioned that the biodegradation capability varied from one strain to another. This was confirmed by studying the degradation of phenol at initial concentrations up to $1000 \mathrm{mg} / \mathrm{L}$ using Candida tropicalis and two other strains named Candida rugosa, and Pichia membranaefaciens isolated from refinery wastewater. Candida tropicalis was able to grow at high phenol concentrations of 500 and $1000 \mathrm{mg} / \mathrm{L}$, while C. rugosa and P. membranaefaciens showed an inhibition effect in presence of $500 \mathrm{mg} / \mathrm{L}$ of phenol [5].

White fungi showed high performance in the area of wastewater treatment. Several types of white rot fungi can achieve biodegradation of toxic compounds such as phenols, polyphenols and aromatic amines, however the removal percentage of the contaminants is lower than that observed using bacteria and yeasts (Table 2) [52,53]. Phanerochaete chrysosporium, a well-known white rot fungus, has a strong capability in the removal of toxic organic pollutants. It was reported that, immobilized white fungus Phanerochaete chrysosporium was used for the coke wastewater treatment. Percentages reduction of phenols and COD were $87.05 \%$ and $72.09 \%$, respectively, in a period of 6 days [59]. Geotrichum sp. and Aspergillus sp. were tested for olive mill wastewater treatment, and up to 55\% COD reduction was achieved using both strains [24].

Microalgae are among the most important microorganisms that have gained increasing attention in the area of wastewater treatment. In this case, ompared to other microorganisms, the produced biomass after wastewater treatment is a valuable product that can be applied in other applications such as biofuel production, nutrition and pharmaceutical applications [48,49]. The number of microalgae strains has the ability to utilize toxic pollutants present in industrial wastewater. Among these strains, Chlorella sp. $[60,61]$ Nannochloropsis sp. $[60,62]$ and Anabaena variabilis are the most commonly used. They showed high performance in the treatment of refinery wastewater, pulp and paper industrial wastewater and olive mill wastewater [51,53]. Although microalgae have been widely applied in the area of wastewater treatment, they achieve low pollutant removal at a high concentration range, as shown in Table 2. The cultivation of Scenedesmus sp. in olive oil mill wastewater highly contaminated with COD concentrations of $49,000 \mathrm{mg} / \mathrm{L}$ and phenol concentrations of $4880 \mathrm{mg} / \mathrm{L}$, were tested. It was found that, a reduction of $22 \%$ and $35 \%$ of phenols and COD were achieved, respectively [20,63]. Compared to complete removal of 2,4-DNP at initial concentration of $190 \mathrm{mg} / \mathrm{L}$ using the same strain [61]. Most of the algal strains were tested for the removal of phenols and reduction of COD from wastewater. However, a pure culture of Chlorella sorokiniana showed high degradability of short-chain organic compounds that are similar to the GTL-processed water. C. sorokiniana has high tolerance for the degradation of ethanol and acetic with removal percentage up to $96.6 \%$, in contrast to only $53.4 \%$ butanol was degraded within 3 days [56]. 
Table 2. Aerobic biodegradation of industrial wastewater using several microorganisms.

\begin{tabular}{|c|c|c|c|c|c|}
\hline Biomass & Wastewater & $\begin{array}{c}\text { Pollutant } \\
\text { Measurement }\end{array}$ & $\begin{array}{l}\text { Initial Concentration } \\
(\mathrm{mg} / \mathrm{L})\end{array}$ & $\begin{array}{l}\text { Removal } \\
(\%)\end{array}$ & Ref. \\
\hline \multicolumn{6}{|c|}{ Activated sludge } \\
\hline \multirow{7}{*}{ Activated sludge } & \multirow[t]{2}{*}{ Coke } & COD & 3275 & 75 & [43] \\
\hline & & Phenols & 807 & 98 & [43] \\
\hline & \multirow[t]{2}{*}{ palm oil mill } & COD & 1000 & 83 & [25] \\
\hline & & COD & 5000 & 42 & [25] \\
\hline & & $\mathrm{BOD}_{5}$ & 440 & 74 & [25] \\
\hline & & $\mathrm{BOD}_{5}$ & 2300 & 39 & [25] \\
\hline & petrochemical & COD & 900 & 89 & [44] \\
\hline \multicolumn{6}{|c|}{ Bacteria } \\
\hline Pseudomonas aeruginosa & municipal & TOC & 230 & 42 & [64] \\
\hline \multirow{3}{*}{ Pseudomonas putida } & Refinery & Phenol & 500-1000 & 100 & [49] \\
\hline & & Phenol & 150 & 90 & [38] \\
\hline & & p-Cresol & 200 & 85 & [65] \\
\hline \multirow[t]{3}{*}{ Bacillus cereus } & Petroleum & TOC & 4548 & 93.4 & [54] \\
\hline & & COD & 9200 & 99.24 & [54] \\
\hline & & $\mathrm{NH} 4+-\mathrm{N}$ & 121.092 & 49 & [54] \\
\hline SludgeHammer & Municipal & TOC & 230 & 70 & [64] \\
\hline Bacillus subtilis & & TOC & 230 & 54 & [64] \\
\hline Bacillus laterosponus & & TOC & 230 & 52 & [64] \\
\hline Pseudomonas aeruginosa & & TOC & 230 & 42 & [64] \\
\hline \multirow[t]{3}{*}{$\begin{array}{c}\text { Stenotrophomonas } \\
\text { acidaminiphila }\end{array}$} & Fermentation & Acetic acid & 208 & 100 & [56] \\
\hline & & Ethanol & 159 & 73.3 & [56] \\
\hline & & Butanol & 110 & 96.3 & [56] \\
\hline \multirow[t]{3}{*}{$\begin{array}{l}\text { Chryseobacterium } \\
\text { scophthalmus }\end{array}$} & & Acetic acid & 208 & 100 & [56] \\
\hline & & Ethanol & 159 & 75 & [56] \\
\hline & & Butanol & 110 & 93.4 & [56] \\
\hline \multicolumn{6}{|c|}{ Yeast } \\
\hline \multirow[t]{2}{*}{ Candida tropicalis } & Olive oil mil & COD & 124,000 & 62.8 & [24] \\
\hline & & Polyphenol & 12,800 & 51.7 & [24] \\
\hline Trichosporon cutaneum & & COD & $19,000-72,000$ & 80 & [58] \\
\hline Y. lipolytica & & COD & $179,000 \pm 2000$ & 50.9 & [57] \\
\hline Candida rugosa & & COD & $179,000 \pm 2000$ & 58.7 & [57] \\
\hline Candida cylindracea & & COD & $179,000 \pm 2000$ & 70.2 & [57] \\
\hline Candida rugosa & & COD & $179,000 \pm 2000$ & 58.7 & [57] \\
\hline Candida cylindracea & & COD & $179,000 \pm 2000$ & 70.2 & [57] \\
\hline \multicolumn{6}{|c|}{ Fungus } \\
\hline Pleurotus ostreatus & Olive oil mill & Phenol & $880-4000$ & 78.3 & [66] \\
\hline \multirow[t]{2}{*}{ Geotrichum sp. } & & COD & 124,000 & 55.0 & [24] \\
\hline & & Polyphenol & $128,00 \mathrm{mg} / \mathrm{L}$ & 46.6 & [24] \\
\hline \multirow[t]{2}{*}{ Aspergillus sp. } & & COD & 124,000 & 52.5 & [24] \\
\hline & & Polyphenol & 12,800 & 44.3 & [24] \\
\hline \multicolumn{6}{|c|}{ Microalgae } \\
\hline Scenedesmus sp & Olive oil mill & COD & 49,000 & 35 & [63] \\
\hline Chlorella pyrenoidosa & Refinery & Phenol & $200 \mathrm{mg} / \mathrm{L}$ & 100 & [62] \\
\hline Scenedesmus sp. & wastewater & 2,4-DNP & $190 \mathrm{mg} / \mathrm{L}$ & 100 & [60] \\
\hline Chlorella sp. & & Phenol & $300 \mathrm{mg} / \mathrm{L}$ & 80 & [67] \\
\hline \multirow[t]{3}{*}{ Chlorella sorokiniana } & fermentation & Ethanol & 159 & 98.9 & [56] \\
\hline & & Butanol & 110 & 53.4 & [56] \\
\hline & & Acetic acid & 208 & 96.6 & [56] \\
\hline
\end{tabular}


In order to increase the efficiency of biological treatment, co-cultured systems of bacteria and microalgae have been applied as an alternative and renewable approach. Generally, organic matter or nutrient removal is oxidized by bacteria in aerobic conditions using an external air supplement, whereas an external supply of $\mathrm{CO}_{2}$ for photosynthesis must be added from microalgae growth [8]. The application of these systems in wastewater treatment will reduce the overall cost of the biological treatment, by avoiding the external supply of $\mathrm{O}_{2}$ required for aerobic conditions of bacteria and $\mathrm{CO}_{2}$ required for microalgae [68]. It was reported that, the combination of immobilized Chlorella vulgaris and suspended activated sludge introduced efficient system for wastewater treatment with high concentration of COD nitrogen and phosphorus. The co-cultured system achieved complete removal of phosphorus, 99.8\% nitrogen removal and 90-95\% COD reduction [8]. This process introduced a stable biological wastewater treatment system for being used in repeated processes [8]. Chlorella vulgaris in immobilized form was also co-cultured with suspended Pseudomonas putida and showed high performance in the reduction of COD, nitrogen and phosphorus. Batch experimental results indicated the stability of the system in the batch mode and suggested the ability of using co-cultured systems in the continuous process for real refinery wastewater treatment [47]. Chavan and Mukherji [45,46], tested phototrophic microorganisms and bacteria for the treatment of wastewater containing diesel oil in rotating biological contractor (RBC). A culture consisted of Cyanobacteria named Phormidium, Oscillatoria, Chroococcus and Burkholderia cepacia bacteria was developed for the removal of total petroleum hydrocarbon (TPH) and COD. The biological system had the ability to remove TPH at a concentration up to $6615.2 \mathrm{mg} / \mathrm{L}$ and achieved a highest removal of $98.99 \%$, in a period of 34 days. In addition, up to $97.19 \%$ COD reduction was obtained at maximum a concentration of $5406.38( \pm 15.52) \mathrm{mg} / \mathrm{L}[45]$. These results highlighted that the application of a co-cultured system is an achievable technology for the treatment of wastewater produced from petroleum refineries and petrochemical industries [45].

Co-culture systems consisting of microalgae and alcohol-degrading bacteria have been proposed for the removal of VFA and alcohol. Co-cultures of Chlorella sorokiniana and Stenotrophomonas acidaminiphila resulted in the complete removal of ethanol, butanol and acetic acid within one day. However, the reduction in butyric acid was achieved during the 3 days of the treatment process $[56,66]$. This study indicated the high performance of the degradation of alcohol by applying a co-culture system consisted of microalgae and bacteria.

\subsubsection{Anaerobic Biological Treatment}

A considerable attention has been made to the development of anaerobic wastewater treatment systems, in which the conversion of the pollutant to biogas usually occurs [69]. Compared to the aerobic techniques, the anaerobic wastewater treatment has several advantages including energy generation and low cost, due to the relatively inexpensive reactors. It is also applicable at any place and scale and the microorganisms can be used over a long period of time [69], whereas the application of anaerobic treatment faced number of drawbacks, including the formation of byproduct, slow start up time and odor production [70]. However, the development of new rectors to overcome these problems was investigated and applied in wastewater treatment. Table 3 shows several reactors that are used under anaerobic conditions in batch and continuous modes, this includes the up-flow anaerobic sludge reactor (UASB), anaerobic moving bed biofilm reactors (AMBBS), anaerobic sequential batch reactor (ASBR), anaerobic fluidized bed reactor (AFBR) and anaerobic baffled reactor (ABR). These reactors were tested using anaerobic microorganisms and showed their ability in the degradation of high strength wastewater. However, their treatment efficiencies depend on several parameters such as initial concentration of toxic compounds, $\mathrm{pH}$ and temperature of the wastewater [69].

Among several anaerobic reactors, the up-flow anaerobic sludge blanket (UASB), is the most commonly used reactor in the area of wastewater treatment. Basically, this reactor can convert the soluble organics present in wastewater into value-added bioenergy during waste the treatment [71]. The treatment of several wastewater streams combined with biogas production were investigated using 
UASB reactors and achieved varying efficient degradation such as $76.3 \%$ COD reduction from refinery wastewater, and biogas production rate of $0.25 \mathrm{~L}$ biogas/L feed [72], 71\% COD and 75\% phenol reduction from coal gasification wastewater [1], reduction phenols and $\mathrm{m}$-cresol of $98 \%$ and $20 \%$, respectively for wastewater stream contained $900 \mathrm{mg} / \mathrm{L}$ of phenol and $320 \mathrm{mg} / \mathrm{L}$ of $\mathrm{m}$-cresol [73]. Although UASB reactors have been widely applied, they still have some limitations, therefore extensive studies were carried out to introduce new bioreactors to overcome these drawbacks. The anaerobic baffled reactor (ABR) have been developed and used for wastewater treatment. The reactor is identified as a series of UASB reactors that are mainly separated with standing baffles which forced the wastewater stream to flow under and over them. In addition to the low capital cost, the reactor has several advantages including low simplicity, mechanical stability, absence of sludge accumulation and stability toward organic shock [55]. Denitrification baffled reactor (DnBR) was also developed and tested for the removal p-cresol under several operation parameters such as initial p-cresol concentration, retention time and salinity. Results showed that p-cresol with initial concentration of $1000 \mathrm{mg} / \mathrm{L}$, was removed completely at hydraulic retention tome of $24 \mathrm{~h} \mathrm{[55].}$

Table 3. Commonly used anaerobic reactors with their advantages and disadvantages.

\begin{tabular}{|c|c|c|c|c|}
\hline Reactor & Description & Advantages & Disadvantages & Reference \\
\hline UASB & $\begin{array}{l}\text { The reactor containing } \\
\text { granular sludge bed is } \\
\text { fed from the bottom. } \\
\text { The reactor has a } \\
\text { tri-phase separator } \\
\text { attached to a gas } \\
\text { collecting bag. } \\
\text { The reactor is } \\
\text { surrounded by } \\
\text { circulating water } \\
\text { jacket for } \\
\text { temperature control. }\end{array}$ & 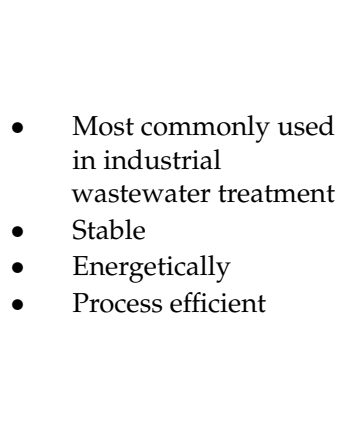 & $\begin{array}{l}\text { Usually requires long } \\
\text { start-up time. } \\
\text { The process initiates } \\
\text { with wash-out of } \\
\text { sludge (except if the } \\
\text { plant is seeded with } \\
\text { granular sludge) } \\
\text { Required good control } \\
\text { of hydraulics and } \\
\text { toxic materials. }\end{array}$ & {$[46,74]$} \\
\hline AnMBR & $\begin{array}{l}\text { It constituted of two } \\
\text { parts: sludge bed and } \\
\text { supernatant where } \\
\text { hollow-fiber membrane } \\
\text { submerged in it. } \\
\text { The reactor is fed from } \\
\text { the bottom. } \\
\text { The reactor is } \\
\text { inoculated } \\
\text { granular sludge } \\
\text { Membrane is installed } \\
\text { after the stabilization of } \\
\text { the reactor. }\end{array}$ & $\begin{array}{l}\text { - High solids retention } \\
\text { Rejection of high } \\
\text { molecular } \\
\text { weight organics. } \\
\text { Less energy usage and } \\
\text { in sludge production. }\end{array}$ & $\begin{array}{l}\text { - } \quad \text { Membrane fouling } \\
\text { High aeration rates are } \\
\text { required except in } \\
\text { gasification where } \\
\text { gases is used } \\
\text { Difficulty to achieve } \\
\text { effective } \\
\text { membrane scouring. }\end{array}$ & {$[67,75,76]$} \\
\hline
\end{tabular}


Table 3. Cont.

\begin{tabular}{|c|c|c|c|c|}
\hline Reactor & Description & Advantages & Disadvantages & Reference \\
\hline FFR & $\begin{array}{l}\text { Biomass is immobilized } \\
\text { in biofilm support } \\
\text { structure (media). } \\
\text { The distribution of } \\
\text { wastewater is from } \\
\text { above/below the media. }\end{array}$ & $\begin{array}{ll}\text { - } & \text { Simple } \\
\text { - } & \text { Absence of } \\
\text { mechanical mixing } \\
\text { - } & \text { More stability at higher } \\
\text { loading rates } \\
\text { - } & \text { Ability to resist large } \\
\text { toxic shock loads. }\end{array}$ & $\begin{array}{l}\text { - } \quad \text { large reactor volume } \\
\text { Clogging of the reactor } \\
\text { caused by biofilm } \\
\text { thickness and/or high } \\
\text { suspended solids. }\end{array}$ & [69] \\
\hline AFBR & $\begin{array}{l}\text { The reactor has } \\
\text { fluidized form of } \\
\text { attached bacteria and } \\
\text { growth media } \\
\text { Drag forces is exerted } \\
\text { by the up } \\
\text { growing wastewater. } \\
\text { The reactor has media } \\
\text { with small particle size } \\
\text { Large surface area is } \\
\text { provided by the media } \\
\text { for biofilm formation } \\
\text { and growth. }\end{array}$ & $\begin{array}{ll}\text { - } & \text { No bed clogging } \\
\text { - } & \text { Low hydraulic } \\
\text { - } & \text { head loss } \\
\text { Better } \\
\text { - } \\
\text { - } & \text { More surface area. } \\
\text { - } & \text { Low cost. }\end{array}$ & $\begin{array}{l}\text { Need bed recycling } \\
\text { that require attachment } \\
\text { of the microorganism } \\
\text { Have big particle size } \\
\text { compared to fixed film } \\
\text { reactor. (depending on } \\
\text { the type of the film) }\end{array}$ & [69] \\
\hline
\end{tabular}

Recently, reactors using granulated biomass were applied for the wastewater treatment of effluents generated from textile industries [77], coking mill [78], domestic and landfill leachate [79]. It was reported that, a pilot scale of anaerobic sequencing batch reactor (ASBR) was applied for COD reduction and gas production. At controlled conditions of one day HRT and organic rate between 0.5 and $1.5 \mathrm{COD} / \mathrm{m}^{3} . \mathrm{d}$, a percentage reduction of $90 \%$ COD was achieved, and high specific methanogenic activity during the biodegradation process was observed [80]. Rajasimman et al. [77] developed a novel modified anaerobic sequential batch reactor (MASBR) for textile dying wastewater treatment. The reactor was modified by adding sorbent and plastic media and tested for the removal of COD, decolorization and biogas production. At optimum condition of initial dye concentration, organic loading and hydraulic retention time (HRT), 94.8\% COD and 97.1\% decolorization reduction were obtained [77]. Anaerobic moving bed biofilm reactor (AMBBR) has also been applied for industrial wastewater treatment. This reactor has several advantages over other anaerobic reactors including high performance in degrading toxic chlorinated organic compounds. Derakhshan et al. [79] investigated the reduction of atrazine and COD using an anaerobic moving bed biofilm reactor (AMBBR). The study illustrated the effect of the operation conditions including initial concentration, hydraulic retention times (HRT) and salinity on the removal efficiency. Under optimum conditions, COD was reduced efficiently $(97.4 \%)$ while only $60.5 \%$ of atrazine was degraded. Monsalvo et al. [76] studied the application of anaerobic membrane bioreactor (AnMBR) for the removal of 38 trace organics present in wastewater. The reactor showed high ability in removing 9 trace chemicals ( $90 \%$ removal), while only $50 \%$ removal was observed for other compounds. The removal of the pollutants in AnMBR was achieved through several mechanisms; biologically, partial absorption, retaining by flocs and deposition. Gao et al. [7] investigated the domestic wastewater purification using an integrated anaerobic fluidized bed bioreactor (IAFMBR). The study tested the effect of the temperature and influent strength on COD reduction, and it was concluded that the highest removal was found at operation temperature of $35^{\circ} \mathrm{C}$.

Anaerobic treatment was applied for the treatment of alcohol-containing wastewater, which is relatively similar in composition to GTL wastewater. The removal of these components was carried out in several anaerobic reactors of which UASB is the most commonly used. Most studies focused on the reduction of COD resulting from the presence of short chain organics, such as methanol and 
ethanol and volatile fatty acids (VFA). Table 4 summarizes anaerobic removal of alcohol and VFA that are the main sources of the COD content in the GTL-processed water.

Table 4. Reduction in COD content caused by the removal of contaminants that present in GTL-processed water.

\begin{tabular}{ccccc}
\hline Reactor Type & COD $(\mathbf{m g} / \mathbf{L})$ & Pollutants & Removal & Ref. \\
\hline UASB & 200 & Ethanol & $95 \%$ & {$[81]$} \\
PBR & $20,000-45,000$ & Alcohols, amines, ketones and & $80 \%$ & {$[82]$} \\
UASB & 1000 & aromatic compounds & $98 \%$ & {$[83]$} \\
ASBR & 20,000 & Alcohol and VFA & $98 \%$ & {$[30]$} \\
UASB & 3.104 & Ethanol and acetate & $96 \%$ & {$[84]$} \\
USR & 5000 & Alcohol and VFA & $90 \%$ & {$[85]$} \\
USR-UASB & 5000 & Alcohol & $99 \%$ & {$[85]$} \\
Anaerobic hybrid reactors & 12,000 & Alcohol & $>95 \%$ & {$[86]$} \\
\hline
\end{tabular}

Han et al. [84] studied anaerobic treatment of low strength wastewater contaminated with ethanol and VFA in UASB using granular sludge. Around 96\% COD reduction was obtained for wastewater feed with COD concentration of $3.104 \mathrm{mg} / \mathrm{L}$ consisted of $1.891 \mathrm{mg}$ COD/L VFA (formate acetate propionate and butyrate) and $1.213 \mathrm{mg}$ COD/L alcohol (ethanol, methanol and butanol). In another study, the anaerobic treatment of alcohol wastewater with a high COD concentration $(5000 \mathrm{mg} / \mathrm{L})$ was compared in two anaerobic reactor systems; the up-flow anaerobic solid reactor (USR) and combined process of USR-UASB. In addition to the high biogas production, the combined process obtained COD reduction of $99 \%$, compared to the USR that achieved $90 \%$ removal [85]. Castilla et al. [83] investigated the biological treatment of a mixture of chemicals in UASB. The treatment process was started with the addition of wastewater containing methanol, followed by adding other chemicals including isopropyl alcohol, acetic anhydride, methyl, ethylene, isopropyl acetate, acrylic acid, and methyl acrylate. Around 95\% COD reduction efficiency was achieved when the reactor was fed with Methanol only. However, the addition of isopropyl alcohol and ethylene glycol led to a drop in the efficiency $(66 \%)$, and almost a complete removal $(98 \%)$ was achieved in the reactor after 43 days, indicating the acclimatization of the activated sludge. This study highlighted the competitive effect of the presence of alcohol and VFA in the aerobic treatment. Intanoo et al. [87] studied the wastewater treatment and hydrogen production from alcohol wastewater with an initial COD of 60,000 $\mathrm{mg} / \mathrm{L}$ in anaerobic sequencing batch reactors (ASBR) under thermophilic conditions. The wastewater consisted of ethanol and VFA with initial concentrations of 3120 and $5080 \mathrm{mg} / \mathrm{L}$, respectively, and achieved only 32\% COD reduction with relatively high production of methane. Other researchers also achieved high COD reduction $(>95 \%)$ using Sulphur reducing bacteria (SRB) in a laboratory-scale anaerobic hybrid reactor. The wastewater feed was characterized with its high COD $(12,000 \mathrm{~g} / \mathrm{L})$ composed of ethanol, propionate and butyrate [86].

The removal of longer chain alcohol $\mathrm{C} 3$ and $\mathrm{C} 4$ has been studied to a limited extent. Henry et al. [88] investigated the removal of C3 and C4 solvents including butanol, isopropanol, isobutanol, sec-butanol and ethyl acetate in a hybrid biomass reactor. They concluded the importance of the adaptation of the biomass in short chain alcohols $\mathrm{C} 1$ and $\mathrm{C} 2$ before staring the biodegradation process. Adapted biomass was able to reduce COD concentration efficiently and achieved COD removal of $97-99 \%$. The reduction of COD concentration that resulted from short-chain alcohol was widely studied. Compared to long-chain alcohols, the removal of short-chain alcohols and VFA was widely studied and high removal efficiencies was obtained. The presence of long-chain alcohols in wastewater was proof of an inhibition effect on the microbial activity and, therefore, a proper adaptation process must be carried out [89]. It is worth mentioning here that the target compounds in the GTL wastewater treatment are short chain alcohols, since $76 \%$ of the COD concentration is due 
to the presence of short-chain alcohol. Thus, the application of anaerobic treatment is shown to be effective for the application of GTL wastewater treatment.

\subsection{Advanced Biological Techniques}

\subsubsection{Immobilization of Biomass}

Immobilization of biomass is a strategy to protect the biomass from the toxicity and inhibition effect of the pollutants in wastewaters. Compared to free-cells, immobilized microorganisms help biomass handling and separation, allowing a high biomass density to be maintained and providing a greater opportunity for reuse and recovery. In addition, immobilization leads to the protection of the microorganisms from harsh operation conditions, including high $\mathrm{pH}$ and elevated temperature, and it also increases the stability of the biomass over long operation periods [11]. Biomass immobilization is divided into two categories: self-immobilization that resulted from the formation of granules when the activated sludge is transformed to compact aggregates [90], and artificial immobilization obtained by the entrapment of the microorganisms into a gel matrix, such as Agar [91], Ca-alginate [10], polyvinyl alcohol [51] and foam glass [92]. The application of cell immobilization has been used for the removal of several toxic compounds under aerobic and anaerobic conditions, in fixed and moving bed reactors, achieving remarkable improvement in the biological treatment process $[64,81,92,93]$. Table 4 introduces the activity of immobilized microorganism in wastewater treatment contaminated with several pollutants, such as phenols, COD, phosphate, nitrate organic carbons and petroleum hydrocarbons.

Under aerobic conditions, immobilized biomass has been used in several types of reactors, including spouted bed bioreactor, fluidized bed bioreactor and trickling packed-bed reactors (Table 5). Granular activated sludge systems such as self-immobilization methods have been widely applied in the area of wastewater treatment and used for the reduction of a number of organic compounds, such as phenols, alcohol and acetate. Compared to conventional sludge, self-immobilization of activated sludge has several advantages including low operation cost, good control over flocculent sludge growth and the elimination of the sedimentation tank and recycling pumps [49,94]. Granular activated sludge was used for the reduction of COD from several wastewater streams under aerobic and anaerobic systems and achieved high removal efficiency, as shown in Table 5.

It was reported that immobilized cells of Rhodococcus erythropolis UPV-1 was prepared by adsorption on the diatomaceous earth. They were found able to grow actively and form biofilm of short filaments. Phenol-acclimatized cells resulted in a complete degradation of phenols from wastewater under optimum culture conditions. It should be mentioned that, the remarkable enhancement in phenol degradation activity is caused by the immobilization and protection of biomass from high strength phenolic wastewater [95]. The immobilization of bacterial cells in polyvinyl alcohol (PVA) gel from refinery wastewater was investigated, an efficient degradation of phenol using immobilized Pseudomonas putida in spouted bed bioreactor (SBBR) was accomplished, with complete removal of phenol from refinery wastewater in less than five hours [51]. Additionally, the immobilized bacteria were also tested for the removal of p-cresol from synthetic wastewater. Continuous biodegradation experiments indicated that, $P$. putida had high potential for the biodegradation of p-cresol at concentrations up to $200 \mathrm{mg} / \mathrm{L}$, with more that $85 \%$ removal efficiency [74]. Jiang et al. [96] isolated Acinetobacter sp. from activated sludge and then immobilized in PVA gel prepared by freezing-thawing cycles. Immobilized Acinetobacter sp. was applied to study the biodegradation of wastewater containing high phenol concentration $(1100 \mathrm{mg} / \mathrm{L})$. Results proved that immobilized cells were capable to remove $99.6 \%$ of phenol at $500 \mathrm{mg} / \mathrm{L}$ initial concentration with a good tolerance to the $\mathrm{pH}$ change and temperature fluctuation. The immobilization of biomass resulted in high stability of the bacteria after reuse for 50 times or storage period of 50 days [96]. It should be mentioned that the activity of the biomass was related to the porous structure of the physically cross-linked PVA gel prepared by freeze-thaw cycles, in which the biomass grows and contributes inside the gel, in addition to 
the prevention of the microorganisms from high pollutant concentration [11]. Recently, Ismail and Khudhair [97] examined the ability of immobilized activated sludge in natural polysaccharide sodium alginate with polyvinyl alcohol, for real-field petroleum wastewater. Biodegradation experiments were tested in a spouted bed bioreactor showed an improvement in the biodegradability of phenols and COD, additionally high stability of the immobilized biomass was observed after 35 days. Lu et al. [59] compared free and immobilized white fungus for coke wastewater treatment. Immobilized fungus was allowed to adsorb and grow onto wood chips of Italian poplar, followed by drying using vacuum freeze desiccator. Compared to free fungi, immobilized cells achieved higher removal of phenolic compounds and COD.

Numerous studies reported the utilization of immobilized biomass for wastewater under anaerobic conditions. The immobilization of the mixed culture presented in the activated sludge was carried out in several supporting materials including pumice, polypropylene and polyurethane (Table 4). Biomass immobilization in anaerobic systems has several advantages such as improving solids retention, reducing the granules formation and reducing or eliminating settling step, therefore leading to a shorter operation time [76]. Sen et al. [105] studied the anaerobic treatment of real textile wastewater using immobilized microorganisms in pumice in a fluidized bed reactor (FBR). The study concluded that, the anaerobic treatment process using immobilized and acclimatized biomass resulted in COD, BOD and color removal of $82 \%, 94 \%$ and $59 \%$, respectively. Ratusznei et al. [76] investigated the biodegradation of wastewater containing $485 \mathrm{mg} / \mathrm{L}$ COD, using immobilized activated sludge in cube particles of polyurethane foam. The biodegradation experiments were carried out in an anaerobic sequencing batch reactors (ASBRs) operated in cycles of $8 \mathrm{~h}$. In addition to the high operation stability of the process after 10 operation days, about $86 \%$ COD was removed from wastewater stream. Haribabua et al. [106] developed new bio-carrier made of polypropylene with low density for domestic wastewater treatment. The inverse fluidized bed bioreactor (IFBR) was operated with an immobilization matrix with density of $870 \mathrm{~kg} / \mathrm{m}^{3}$ and surface area of $524 \mathrm{~mm}^{2}$ per particle, in continuous mode. The effect of operation parameters including superficial gas velocity, initial concentration, bed height and hydraulic retention time (HRT), on the COD reduction were investigated. A maximum reduction of $97.5 \%$ COD was obtained at optimum conditions, highlighting the high efficiency of the system using the new immobilization matrix [106].

Immobilized biomass was also applied for the treatment of alcohol-containing wastewater using tezontle material as bio-filtration (tezontle-BF) and granulated activated carbon (GAC) under anaerobic conditions. Both immobilization matrices were tested and compared for the reduction of COD from wastewater contaminated by organic materials consisted of alcohols, amines, ketones and aromatic compounds. Results showed that GAC is more effective in COD reduction, since $80 \%$ COD reduction was obtained using GAC in 40 days, while the use of tezontle-BF required 145 days to obtain similar removal. Thus the use of GAC as immobilization material resulted in greater biodegradation rates and increased the resistance of the bio-filter to high organic load; it also minimized substrate toxicity and inhibition effect [82].

The application of granulation activated sludge or the immobilization of biomass is good alternative for the conventional biological treatment systems. Immobilized biomass including activated sludge can be applied to improve the reduction of COD from wastewater, especially for high strength wastewater such as GTL-processed water. 
Table 5. Immobilization of microorganism for biological wastewater treatment under aerobic and anaerobic conditions.

\begin{tabular}{|c|c|c|c|c|c|c|}
\hline Reactor & Biomass & Immobilization Matrix & Major Pollutants & Pollutant Removal (\%) & COD Reduction (\%) & Ref. \\
\hline & \multicolumn{6}{|c|}{ Aerobic Biodegradation } \\
\hline \multirow{4}{*}{ Packed bed reactor (PBR) } & \multirow{4}{*}{ Bacillus cereus } & \multirow{4}{*}{ Ca-alginate } & TOC & 95.4 & \multirow{4}{*}{99.2} & \multirow{4}{*}{ [54] } \\
\hline & & & Phenol & 99.8 & & \\
\hline & & & $\mathrm{PO}_{3}-\mathrm{P}$ & 44.4 & & \\
\hline & & & $\mathrm{NH} 4^{+}-\mathrm{N}$ & 49.3 & & \\
\hline \multirow{2}{*}{ Bioreactors } & \multirow{2}{*}{ Chlorella vulgaris } & \multirow{2}{*}{ Ca- alginate } & $\mathrm{PO}_{3}-\mathrm{P}$ & 95 & \multirow{2}{*}{-} & \multirow{2}{*}{ [98] } \\
\hline & & & $\mathrm{NH} 4^{+}-\mathrm{N}$ & 100 & & \\
\hline \multirow{3}{*}{$\begin{array}{l}\text { Spouted bed bioreactor } \\
\text { (SBBR) }\end{array}$} & Activated sludge with dominant types of & \multirow{3}{*}{$\begin{array}{l}\text { polysaccharide sodium } \\
\text { alginate with polyvinyl } \\
\text { alcohol }\end{array}$} & & \multirow{3}{*}{66.6} & \multirow{3}{*}{61.7} & \multirow{3}{*}{ [97] } \\
\hline & Pseudomonas & & Petroleum & & & \\
\hline & $\begin{array}{l}\text { Bacillus } \\
\text { E.coli }\end{array}$ & & & & & \\
\hline \multirow{2}{*}{ Bioflo 2000 fermenter } & \multirow{2}{*}{ Candida tropicalis $Y M E C 14$} & \multirow{2}{*}{ Ca-alginate } & Monophenols & 69.2 & \multirow{2}{*}{69.7} & \multirow{2}{*}{ [10] } \\
\hline & & & Polyphenols & 55.3 & & \\
\hline $\begin{array}{l}\text { Fluidized bed bioreactor } \\
\text { (FBR) }\end{array}$ & Pseudomonas putida & Sodium alginate & Phenols & $<90$ & - & [49] \\
\hline \multirow{3}{*}{$\begin{array}{l}\text { Trickling packed-bed } \\
\text { reactors (TPR) }\end{array}$} & \multirow{3}{*}{$\begin{array}{l}\text { Mycelial suspensions of Phanerochaete chrysosporium } \\
\text { Trametes versicolor } \\
\text { Lentinula edodes }\end{array}$} & \multirow{3}{*}{ Foam glass beads } & Phenols & $<98$ & \multirow{3}{*}{-} & \multirow{3}{*}{ [92] } \\
\hline & & & & ( & & \\
\hline & & & $2,+10+10$ & & & \\
\hline Batch flaks & Acinetobacter $s p$ & PVA gel & Phenol & 99.6 & - & {$[96]$} \\
\hline Batch flasks & Acinetobacter sp. and Sphingomonas sp & PVA gel & Phenol & $<95$ & - & [99] \\
\hline Spouted bed bioreactor & Pseudomonas putida & PVA gel & Phenol & 100 & - & [51] \\
\hline Aeration tank & Rhodobacter shaeroide & $\begin{array}{l}\text { Alginate } \\
\text { Agar }\end{array}$ & Oil & 96 & - & [91] \\
\hline \multirow{3}{*}{ Lakes } & \multirow{3}{*}{$\begin{array}{l}\text { Ten strains with Pseudomonas, Coccus, Aeromonas, } \\
\text { Bacillus, and Enterobateriaceae as dominant types. }\end{array}$} & \multirow{3}{*}{ Diatomite } & TOC & 80.2 & \multirow{3}{*}{-} & \multirow{3}{*}{100} \\
\hline & & & $\mathrm{TP}$ & 81.6 & & \\
\hline & & & $\mathrm{TN}$ & 86.8 & & \\
\hline $\begin{array}{l}\text { Batch experiment in } \\
\text { Flasks }\end{array}$ & $\begin{array}{l}\text { Rhodotorula mucilaginosa, Streptomyces albidoflavus } \\
\text { Micrococcus luteus }\end{array}$ & polyurethane foam & Nitrobenzene & 100 & - & [101] \\
\hline $\begin{array}{l}\text { A column-type sequential } \\
\text { aerobic sludge blanket } \\
\text { reactor }\end{array}$ & Activated sludge & Granular & Phenol & - & - & [102] \\
\hline
\end{tabular}


Table 5. Cont

\begin{tabular}{|c|c|c|c|c|c|c|}
\hline Reactor & Biomass & Immobilization Matrix & Major Pollutants & Pollutant Removal (\%) & COD Reduction (\%) & Ref. \\
\hline $\begin{array}{l}\text { Pilot scale sequencing } \\
\text { batch reactor }\end{array}$ & Activated sludge & Granular & Organics & & 95 & [103] \\
\hline \multirow[t]{2}{*}{$\begin{array}{l}\text { Sequential batch reactor } \\
\text { system (SBR) }\end{array}$} & Activated sludge & Granular & Organics & & 94 & [104] \\
\hline & \multicolumn{6}{|c|}{ Anaerobic Biodegradation } \\
\hline Fluidized bed bioreactor & Anaerobic sludge & Pumice & Organics & - & 82 & [105] \\
\hline Fluidized bed bioreactor & Activated sludge & $\begin{array}{l}\text { low density } \\
\text { polypropylene }\end{array}$ & Organics & & 97.5 & [106] \\
\hline $\begin{array}{l}\text { Anaerobic sequencing } \\
\text { batch reactors (ASBRs) }\end{array}$ & Activated sludge & polyurethane foam & Organics &.- & 86 & [76] \\
\hline $\begin{array}{l}\text { Upflow anaerobic sludge } \\
\text { blanket (UASB) }\end{array}$ & Activated sludge & Granular & Organics & - & 96 & [84] \\
\hline $\begin{array}{l}\text { Expanded Granular } \\
\text { Sludge Bed Reactors } \\
\text { (EGSB) }\end{array}$ & Activated sludge & Granular & Organics & - & 80 & [81] \\
\hline $\begin{array}{l}\text { Packed bed Reactors } \\
\text { (PBR) }\end{array}$ & Activated sludge & $\begin{array}{l}\text { Granulated activated } \\
\text { carbon (GAC) and a } \\
\text { porous stone called } \\
\text { tezontle }\end{array}$ & Organics & - & 80 & [82] \\
\hline
\end{tabular}




\subsubsection{Use of Nanotechnology in Biological Treatment}

Biomass immobilization in a solid matrix has major drawbacks, including poor strength, instability at low $\mathrm{pH}$ and poor mechanical properties. Although several studies are available on the use of the polymeric agents for cell immobilization, there are still limited studies focusing on the use of magnetic nanoparticles for bio-sorbent immobilization. The application of magnetic nanoparticles in the cell immobilization increases the stability and enzymatic activity as was reported by Dyal et al. [107], who highlighted a great improvement in the enzymatic activity and the stability of Candida Rugosa lipase, after the immobilization on $\gamma-\mathrm{Fe}_{2} \mathrm{O}_{3}$ magnetic nanoparticles. Yong et al. [108] also used $\mathrm{Fe}_{2} \mathrm{O}_{3}$ nanoparticles for cell immobilization and obtained a remarkable improvement in the thermal stability of the enzymes. The use of nanoparticles as additives in the immobilization matrix have been widely applied in the area of wastewater treatment, however, most studies concentrated on the heavy metal removal from biological systems. Peng et al. [109] studied the immobilization of Saccharomyces cerevisiae on the surface of chitosan-coated magnetic nanoparticles (SICCM) prepared using $\mathrm{Fe}_{3} \mathrm{O}_{4}$, for the removal of $\mathrm{Cu}$ (II) from wastewater. More than $90 \%$ of $\mathrm{Cu}$ (II) was removed in less than 10 min indicating high biodegradation rates due to the internal diffusion resistance and high specific surface area of the bio-carrier. $\mathrm{Fe}_{3} \mathrm{O}_{4}$ nanoparticle was also used for biomass immobilization and applied for the removal of $\mathrm{Cr}(\mathrm{VI})$. It was reported that, bio-functional magnetic beads consisting of Rhizopus cohnii powder and $\mathrm{Fe}_{3} \mathrm{O}_{4}$ particles coated with alginate and polyvinyl alcohol (PVA) were prepared, and tested for $\mathrm{Cr}(\mathrm{VI})$ removal. In addition to the complete removal of $\mathrm{Cr}(\mathrm{VI})$ from wastewater, the prepared beads showed high mechanical stability at convenient experimental condition [110]. Xu et al. [111] investigated the use of Ca-alginate combined with iron oxide magnetic nanoparticles (MNPs), for the immobilization of Phanerochaete chrysosporium. The immobilized microorganism was applied for the removal of $\mathrm{Pb}$ (II) at concentration up to $500 \mathrm{mg} / \mathrm{L}$, and resulted in a maximum removal of $96.03 \%$ after $8 \mathrm{~h}$.

Few studies examined the application of magnetic additives in the immobilization matrix for COD reduction from wastewater. Zhou et al. [112] compared COD reduction using microorganisms immobilized on $\mathrm{Fe}_{3} \mathrm{O}_{4} / \mathrm{PUF}$ composite with $5 \% \mathrm{Fe}_{3} \mathrm{O}_{4}$, and microorganism immobilized into pure polyurethane foam (PUF) composite. Although both immobilized microorganisms were able to reduce COD content efficiently from wastewater, the addition of $\mathrm{Fe}_{3} \mathrm{O}_{4}$ in the immobilization composite resulted in higher COD reduction. Recently Fan et al. [14] studied the dye adsorption and biodegradation using Pseudomonas pudida immobilized in core shell $\mathrm{Fe}_{3} \mathrm{O}_{4} @ \mathrm{MIL}-100(\mathrm{Fe})$. The core shell nanoparticles were attached to the bacterial cells by a carbon-diimide cross-linking method and used for dyes degradation. Complete removal was achieved using bionanocomposite over a period of $5 \mathrm{~h}$, compared to $11 \mathrm{~h}$ using free bacteria. Moreover, bionanocomposite showed good cycling performance for dye removal with easy separation of the immobilized biomass from the solution using magnetic field characteristics, which makes it a suitable alternative for dye removal [14].

These studies showed that the use of nanoparticles in cell immobilization can be considered as a high performance and cost-effective method for heavy metal removal from wastewater, and for the removal of other pollutants from several types of wastewaters including GTL wastewater. Additionally, the presence of these additives in the immobilized carrier will enhance the stability and offer the possibility of the use of biomass over long period of time.

\section{GTL Wastewater}

\subsection{GTL Process and Wastewater Generation}

Nowadays, natural gas is taking a more important share in the global energy market compare to other fossil fuel sources. Natural gas conversion to liquids, through the (GTL) process, is achieved using several chemical reaction paths ending with the formation of a range of hydrocarbon products. The Fischer-Tropsch (F-T) process is the most widely applied, this process basically involves the conversion of $\mathrm{CO}$ and $\mathrm{H}_{2}$ into several hydrocarbon derivatives [113]. The products of this process can be used directly as fuel such as gasoline, kerosene and diesel, in addition to other special products 
including lubricants [114]. The produced gas using $\mathrm{F}-\mathrm{T}$ process usually has low sulfur and aromatic compound contents [115]. In addition, the low $\mathrm{CO}_{2}$ emission, nitrogen oxides, hydrocarbons, and other particulates make GTL process an environmental friendly alternative and one of the cleanest burning fuels [116]. The GTL process mainly contains three main stages (Figure 1); synthetic gas production where the natural gas steam reforms to produce syngas $\left(\mathrm{CO}\right.$ and $\left.\mathrm{H}_{2}\right)$, followed by the Fischer-Tropsch (F-T) reaction to form hydrocarbons, and syncrude. Finally, upgrading the liquids in which liquid hydrocarbons are formed by cracking and hydro-processing. Then, the produced hydrocarbons products meet market specifications [114].

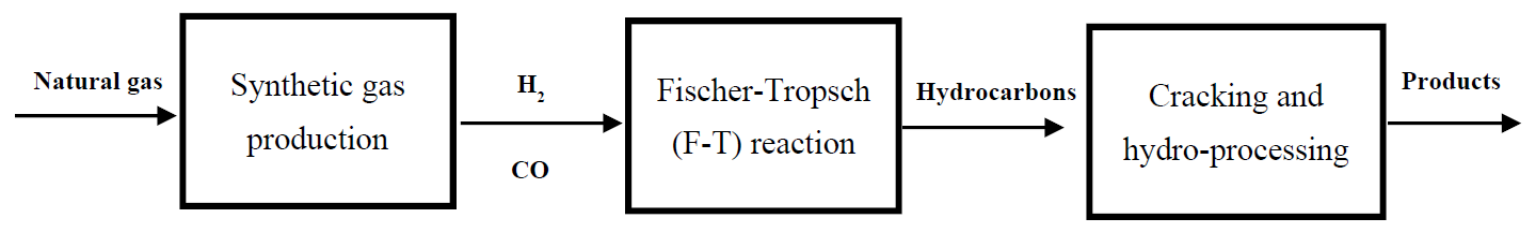

Figure 1. Flow diagram of the gas to liquid (GTL) process with main units and generated wastewater streams [114].

Generally, most of the GTL water is produced from F-T reaction units, in addition to small contribution from blowdown of cooling towers, boilers, hydrogen production unit, synthesis gas unit, caustic and sulphuric storage units [15]. The $\mathrm{F}-\mathrm{T}$ reaction unit produces considerable amount of water; it is estimated that every ton of liquid fuel results in the production of 1.1-1.3 tons of produced GTL water [28]. This can be represented by the following reaction:

$$
(2 \mathrm{n}+1) \mathrm{H}_{2}+\mathrm{nCO} \rightarrow \mathrm{C}_{\mathrm{n}} \mathrm{H}_{2 n+2}+\mathrm{n} \mathrm{H}_{2} \mathrm{O}
$$

\subsection{The Nature of Gas to Liquid (GTL) Process Wastewater}

Wastewater from typical GTL plant generally contains a high concentration of dissolved solids, since the produced cooling water from the blowdown system contains inorganic salts. The total organic compounds are generally measured collectively as COD; besides, GTL wastewater contains number of inorganic compounds including metals, chloride, sulphate, acetate, bicarbonate and dissolved gases such as $\mathrm{H}_{2} \mathrm{~S}$ and $\mathrm{CO}_{2}$ [117]. The contaminants that are present in GTL wastewater vary according to the GTL process unit. The F-T unit results in wastewater contaminated with inorganic compounds and oxygenated hydrocarbons. However, cooling tower and blow down water has significant concentration of dissolved solids, suspended solids and heavy metals. The steam generation unit generates water with high concentration of dissolved solids and minerals. Additionally, wastewater with emulsified oil and other hydrocarbons is often generated in the process area, equipment wash and maintenance activities [118].

In particular, the characterization of $\mathrm{F}-\mathrm{T}$ reaction wastewater depends on the reaction conditions, such as type of catalytic metal, temperature and pressure. The composition of the typical F-T water are presented in Table 6. 
Table 6. Composition of F-T reaction water from different F-T synthesis operating modes [118].

\begin{tabular}{cccc}
\hline Component & Cobalt Catalyst (LTFT) & Iron Catalyst (LTFT) & Iron Catalyst (HTFT) \\
\cline { 2 - 4 } & \multicolumn{1}{c}{ Mass \% } & \\
\hline Water & 98.89 & 95.7 & 94.22 \\
Non-acidic oxygenated & 1 & 3.57 & 4.47 \\
$\quad \begin{array}{c}\text { hydrocarbons } \\
\text { Acidic oxygenated } \\
\text { hydrocarbons }\end{array}$ & 0.09 & 0.71 & 1.4 \\
Other hydrocarbons & 0.02 & 0.02 & 0.02 \\
Inorganic compounds & $<0.005$ & $<0.005$ & $<0.005$ \\
\hline
\end{tabular}

The produced water from $\mathrm{F}-\mathrm{T}$ reaction process usually contains acidic contaminants and dissolved hydrocarbons including acids, ketones, alcohol, aldehydes, acetates and other oxygenates that are mainly light alcohols which represent the main source of COD [113]. F-T process water is highly acidic with a $\mathrm{pH}$ of 3.0, and it characterized with its high COD content ranging from 29,000 to $31,000 \mathrm{mg} / \mathrm{L}$. It also has high BOD content $(9540.5-11,555.4 \mathrm{mg} / \mathrm{L})$ and TOC concentration in the range of $11,853.3-13,116.9 \mathrm{mg} / \mathrm{L}[16,17]$.

Figure 2 shows the main categories of COD sources with an approximate concentration of COD for each group of hydrocarbons. Short chain alcohol SCA such as methanol, ethanol, propanol and butanol form around $76 \%$ of the total COD content. However, long-chain alcohol LCA (hexanol, heptanol, octanol, nananol and decanol) present only $8.2 \%$ of the total COD. The rest of COD content is divided into $10.7 \%$ acids and $4.5 \%$ hydrocarbons.

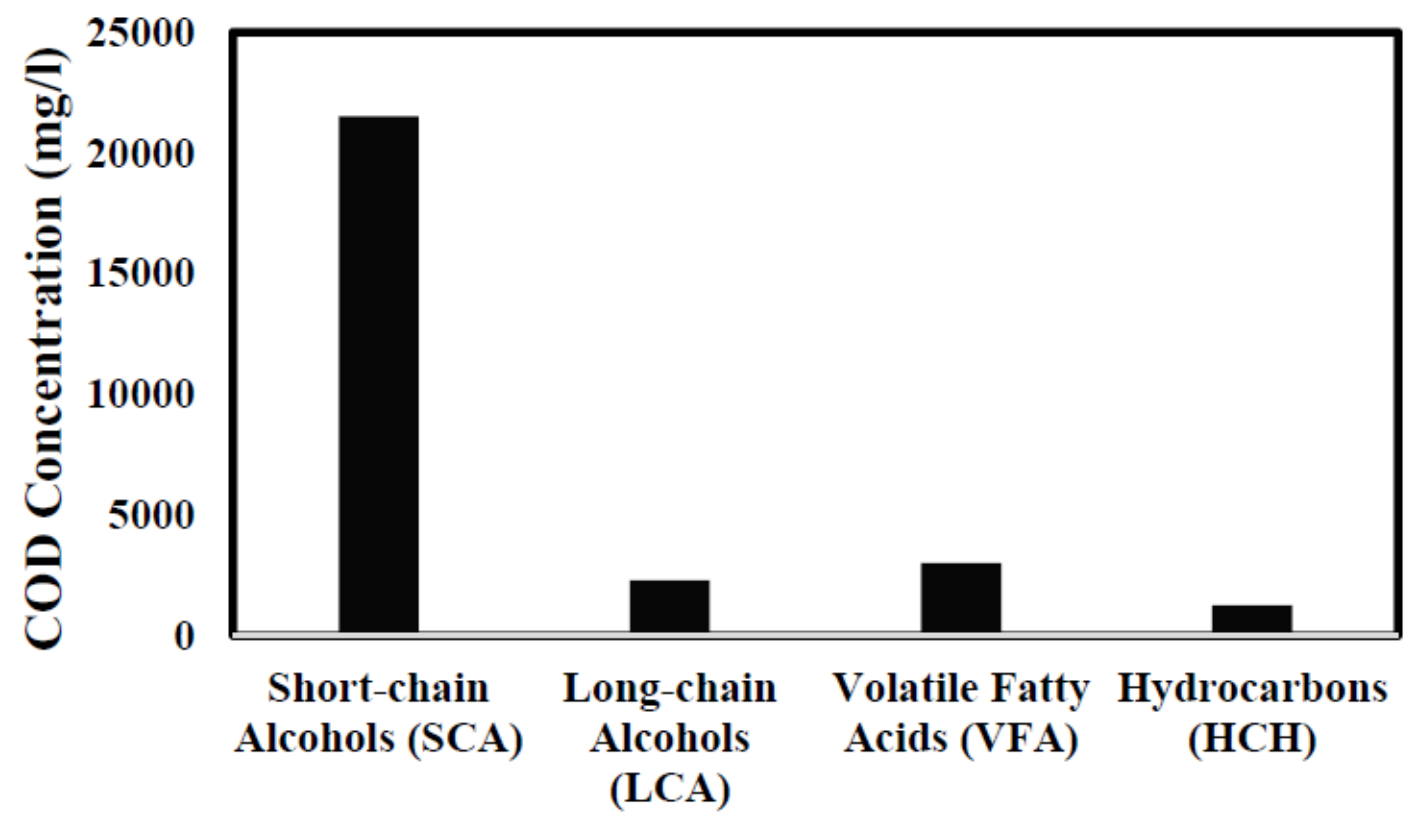

Figure 2. F-T wastewater composition with COD concentration.

\subsection{Methods for GTL Wastewater Treatment}

Various technologies have been applied in the treatment of GTL produced water depending on the characterization of the stream. These techniques such as membrane filtration, advanced oxidation process, thermal evaporation and bioreactors vary in their removal efficiency of the toxic compounds from GTL wastewater [119]. A typical GTL wastewater treatment plant consists of combination of two or more treatment technologies; however due to the negligible amounts of sulfur and nitrogen in GTL wastewater, that are highly distributed in other wastewater streams, GTL wastewater is mainly treated 
by the anaerobic biological digester. The conventional GTL wastewater treatment plant is composed of coarse screening to remove large materials, followed by biological treatment process to remove the soluble materials by adding coagulant. Then, a separation step using coagulation to collect the produced waste in colloidal form. After coagulation, wastewater is treated by adding oxidizing and disinfecting agents to reduce (BOD) level [15].

A case study was reported by Onwusogh [117], where catalytic wet air oxidation (cWAO) was applied as a pretreatment stage in GTL from GTL plant located in Qatar. The unit was placed before an activated sludge unit and used to study the removal of COD with special attention to the kinetic hydrate inhibitors (KHI). CWAO was compared with holding tank as an applied pre-treatment step in the GTL wastewater treatment. The study concluded that cWAO is a feasible and efficient technique to break down KHI into small molecules and reduce the content of COD in the water effluent that will be injected to the biological treatment stage.

Based on the characterization data of particularly F-T process water, light oxygenates such as $\mathrm{C}_{1}-\mathrm{C}_{3}$ alcohols and carbonyl compounds that have boiling points lower than that of water are typically removed using distillation or stripping columns and are valorized as feedstock using a saturator. The residual product from such distillation wastewater which, still had great number of residual alcohols and organic acids that resulted in high COD content $(30 \mathrm{~g} \mathrm{COD} / \mathrm{L})$ and low $\mathrm{pH}$ value $(\mathrm{pH}=3.0)$, are transferred to the biological treatment unit $[95,106]$. However, the use of traditional anaerobic suspended sludge process could be a huge challenge even though the $\mathrm{pH}$ value is equal to 7.0. Pon Saravanan and Van Vuuren [118] reported the treatment of GTL wastewater using three treatment steps, consisting of chemical, biological and physical treatment technologies. The integrated three-step GTL treatment plant, started with primary treatment to treat free oil and suspended hydrocarbons using chemical treatment method, followed by biological treatment in the aeration tank to remove carbonaceous and nitrogenous compounds and finally tertiary treatment method in which physical treatment such as sand filtration is applied to remove suspended solids, oil and associated COD and BOD.

\subsection{Biological Treatment of GTL Wastewater}

Most of the COD content in the integral GTL wastewater stream is due to alcohols, and this water can be successfully treated biologically under anaerobic conditions. The combination of anaerobic and aerobic processes can be suitable for the treatment as well. Beside the removal of organic pollutants from GTL wastewater, the anaerobic process can also produce energy by achieving methane production as byproduct, this make anaerobic biological treatment more preferable [120].

The biological treatment of GTL wastewater, specially F-T wastewater was subject to several studies ranging from laboratory bench scale to pilot scale using synthetic and real wastewater, where the biological treatment was investigated under anaerobic conditions [16]. Majone et al. [113] studied the biodegradation of synthetic F-T wastewater with high COD content (around 28,000 mg/L) resulted from long-chain alcohol using a continuous-flow packed-bed biofilm reactor in lab scale. They gradually increase the content of COD in the tests in order to investigate the inhibitory effect of long-chain alcohol concentration.

The organic load and long-chain alcohol concentration were gradually increased up to $20 \mathrm{~g} \mathrm{COD} / \mathrm{L} / \mathrm{d}$, and the reactor performance was monitored in terms of COD reduction, methane production, and effluent concentration of major components. They concluded that $80 \%$ of COD was reduced through $\mathrm{H}_{2}$ or acetate reactions. Moreover, the residual effluent COD from the anaerobic reactor consisted of acetic and propionic acids that can be easily degraded under aerobic conditions [113]. It should be mentioned that the key factor of the successful F-T wastewater treatment is avoiding the excessive accumulation of butyric acid and propionic acid that can be achieved by reducing Hydraulic Retention Time (HRT) and lower $\mathrm{pH}$ value in system [121].

As mentioned in Section 3.2 most of the COD content results from short chain alcohol (SCA) that can be anaerobically degraded and converted into methane (Figure 3). Based on the wastewater 
effluent composition, the conversion of alcohol is obtained through a set of reactions into methane gas (reactions (1) to (5)). Methanol is directly converted into methane, and the hydrocarbons are not degraded in the process. Other alcohols and VFAs longer than acetate are converted by $\mathrm{H}_{2-}$ and acetate-releasing oxidation reactions; the released acetate and $\mathrm{H}_{2}$ accounts for methane production [113].

$$
\begin{gathered}
\mathrm{CH}_{3} \mathrm{OH}+2 \mathrm{H}_{2} \mathrm{O} \rightarrow \mathrm{HCO}_{3}^{-}+\mathrm{H}^{+}+3 \mathrm{H}_{2} \\
\mathrm{C}_{2} \mathrm{H}_{5} \mathrm{OH}+\mathrm{H}_{2} \mathrm{O} \rightarrow \mathrm{CH}_{3} \mathrm{COO}^{-}+\mathrm{H}^{+}+2 \mathrm{H}_{2} \\
\mathrm{C}_{3} \mathrm{H}_{7} \mathrm{OH}+\mathrm{H}_{2} \mathrm{O} \rightarrow \mathrm{C}_{2} \mathrm{H}_{5} \mathrm{COO}^{-}+\mathrm{H}^{+}+2 \mathrm{H}_{2} \\
\mathrm{C}_{4} \mathrm{H}_{9} \mathrm{OH}+\mathrm{H}_{2} \mathrm{O} \rightarrow \mathrm{C}_{3} \mathrm{H}_{7} \mathrm{COO}^{-}+\mathrm{H}^{+}+2 \mathrm{H}_{2} \\
\mathrm{C}_{5} \mathrm{H}_{11} \mathrm{OH}+\mathrm{H}_{2} \mathrm{O} \rightarrow \mathrm{C}_{4} \mathrm{H}_{9} \mathrm{COO}^{-}+\mathrm{H}^{+}+2 \mathrm{H}_{2}
\end{gathered}
$$

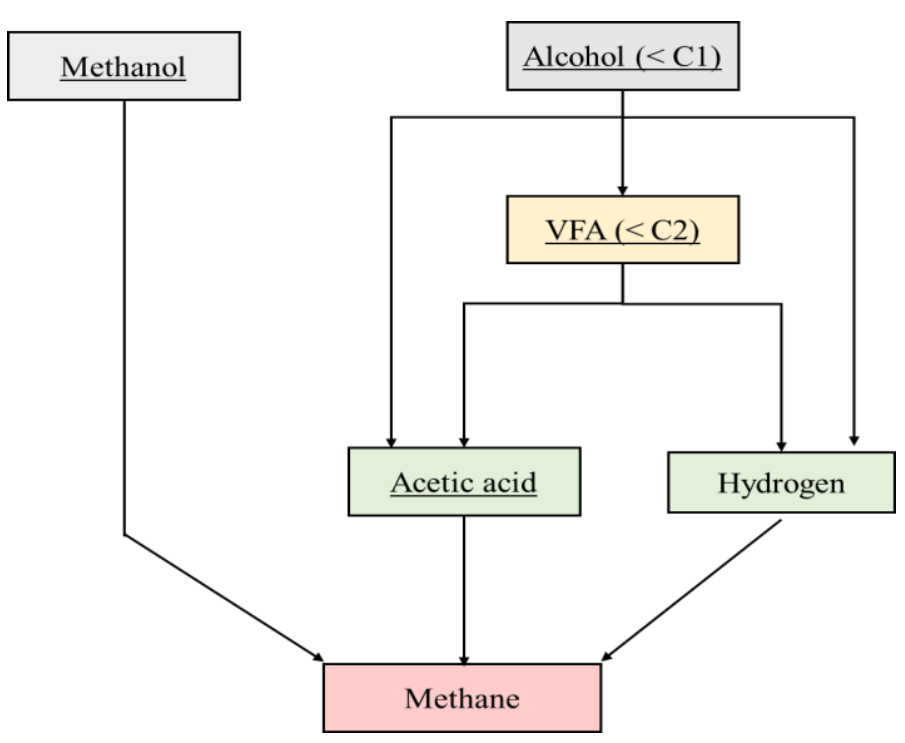

Figure 3. pathway of the anaerobic conversion of alcohol to methane [113].

It should be mentioned here that anaerobic treatment of $\mathrm{F}-\mathrm{T}$ wastewater showed high inhibition effect to the microorganisms caused by the presence of long-chain alcohols (from 6 to $10 \mathrm{C}$ atoms) that represents around $7.6 \%$ of the total COD content. The inhibition effect of these alcohols can be overcome through the adaptation of microorganism before the treatment process [113]. Additionally, the use of anaerobic biological treatment must be enhanced by combining it with an aerobic process for the treatment of high organic load rates.

Combination of the anaerobic biological treatment with the chemical techniques to overcome the incomplete degradation problem for long chain alcohol in high organic load was introduced by other researchers $[15,16]$. Bio-electrochemical systems (BES), that are based on the use of electrochemically active bacteria as catalyst for oxidation and/or reduction reactions at the anode and/or the cathode, has been applied in F-T wastewater treatment $[16,111]$. In addition to the improvement in the treatment performance, an enhancement in biogas production was achieved by coupling anaerobic digester with a BES [94,96]. Wang et al. [17] used Bio-electrochemical system (BES) parallel to the up-flow anaerobic sludge blanket (UASB) to enhance the treatment of F-T wastewater treatment characterized with high COD concentration (from 29,000-31,000 mg/L). The role of electric field in this system were to offer more reductive microenvironment that maintain the $\mathrm{pH}$ range, and reduce the values of oxidation-reduction potential (ORP). The applied treatment process was able to increase COD \% reduction and methane production from $72.1 \%$ and $1.77 \mathrm{~L} / \mathrm{L} . \mathrm{d}$ in the control group, to the values of $86.8 \%$ and $2.31 \mathrm{~L} / \mathrm{L} . \mathrm{d}$, in BES-UASB, respectively [17]. A micro-electrolysis cell (MEC) system was applied and engaged with 
up-flow anaerobic sludge blanket (UASB) system for F-T wastewater treatment at pilot scale level. The wastewater treatment system consisted of a regulating tank for $\mathrm{pH}$ adjustment, an MEC system and, finally, a UASB reactor. The application of this system resulted in reducing the $\mathrm{pH}$ influent to the value of 4.99 at the final operation stage, in addition to the maximum COD reduction and methane production of $93.5 \%$ and $2.01 \mathrm{~m}^{3} / \mathrm{m}^{3} . \mathrm{d}$, respectively [122].

Furthermore, biological systems can be combined with chemical agents, such as Zero valent iron (ZVI) that is generally utilized as a reductive agent for pollutants control. Recently, scrap Zero valent iron ZVI was applied and combined with the biological systems for F-T wastewater treatment in order to reduce the process cost and improve the anaerobic biological treatment [123]. SZVI was used in up-flow anaerobic fixed bed (UAFB) reactor to study the F-T wastewater purification and compared with controlled UAFB reactor. The role of SZVI was to buffer the acidity of the raw wastewater, and at the same time introduce more reductive microenvironment for methanogens. The obtained results indicated enhancement in the COD reduction and methanol production of $11.2 \%$ and $0.42 \mathrm{~L} / \mathrm{L} . \mathrm{d}$, respectively [123]. Although the use of ZVI in the anaerobic biological system could be suitable for generating iron oxides (IO) and enhancing the removal efficiency, it may not be used for pilot scale applications. Direct addition of ZVI shavings or powder may cause a rise in iron precipitation, hence, it was suggested for use in plate electrodes [42].

\section{Summary and Future Prospective}

Several researchers have focused their efforts, in recent years, on the aerobic and anaerobic biological treatment of industrial wastewater, in which several reactors were developed to reduce the concentration of organic compounds to the acceptable limit. Most of the studies available in the open literature concentrated on the reduction of, COD and TOC from industrial wastewater using pure culture or mixed culture consisted of yeast, bacteria fungus and microalgae. Among them, the removal of alcohol and VFA that are considered as major contaminants in GTL wastewater are rarely studied under aerobic conditions; however, the removal of the alcohols and VFA is well documented using several anaerobic reactors. Although advanced biological treatments, such as cells immobilization and application of bio-nanotechnology for industrial wastewater treatment have been thoroughly reviewed in the literature, the number of studies that have highlighted the biological treatment of GTL wastewater, which is mainly generated from F-T process, are rather limited. Anaerobic biological treatment showed good performance in the F-T wastewater treatment, but it still suffers from some drawbacks, including the accumulation of butyric acid and propionic acid, as well as the generation of considerable amounts of sludge. To overcome this drawback, it is often suggested to optimize the anaerobic biological treatment process or to combine anaerobic biological treatment with an aerobic treatment processor to modify the anaerobic reactor by adding a chemical treatment step. This combination, however, may possess some disadvantages, such as high cost and long start up time.

Detailed knowledge on the development of biological treatment of GTL wastewater is still lacking in the literature; thus, future research is recommended in this area in order to improve GTL wastewater treatment process. Biological treatment of GTL wastewater, especially F-T process, using pure culture or co-cultured system under aerobic conditions should be further investigated with more emphasize on process cost and retention time reduction as well as complete degradation of the organic compounds in the wastewater. The biological system must be improved by addressing biomass immobilization in suitable carriers and introducing new nanoparticles that has low cost and more effective at the same time. This may also improve the strength and durability of the process and makes the GTL wastewater treatment applicable and scalable. Finally, reactor design and modeling of new reactors with immobilized biomass must be re-examined, and considerable attention must be given to the optimization of the biological treatment of GTL wastewater for a better removal efficiency of organic pollutants at lower costs and more stable processes. 
Author Contributions: Investigation, R.S., M.H.E.-N. and A.B.; resources, R.S., F.A.-N. and U.O.; data curation, R.S. and F.A.-N.; writing — original draft preparation, R.S., M.H.E.-N. and M.C.M.V.L.; writing—review and editing, R.S., M.H.E.-N. and M.C.M.V.L.; visualization, R.S.; supervision, M.H.E.-N. and M.C.M.V.L.; project administration, M.E and A.B; funding acquisition, M.H.E.-N. All authors have read and agreed to the published version of the manuscript.

Funding: This research was funded by Qatar National Research Fund (a member of Qatar Foundation) through Grant \# NPRP 100129170278.

Acknowledgments: The authors would like to acknowledge the support of Qatar National Research Fund (a member of Qatar Foundation) through Grant \# NPRP 100129170278. The findings achieved herein are solely the responsibility of the authors.

Conflicts of Interest: The authors declare no conflict of interest.

\section{Nomenclature}

ABR

AFBR

AMBBR

AMBBS

AnMBR

ASBR

BES

BOD

COD

cWAO

DNP

DnBR

FBB

FBR

FFR

F-T

GAC

GTL

$\mathrm{HCH}$

HRT

IAFMBR

LCA

MASBR

MEC

MNPs

NAO

OC

ORP

PBC

RBR

PUF

PVA

SBBR

SCA

SRB

TCE

TDS

TOC

TPH

TPR
Anaerobic Baffled Reactor

Anaerobic Fluidized Bed Reactor

Anaerobic Moving Bed Biofilm Reactor

Anaerobic Moving Bed Biofilm Reactors

Anaerobic Membrane Bioreactor

Anaerobic Sequential Batch Reactor

Bio-Electrochemical System

Biological Oxygen Demand

Chemical Oxygen Demand

Catalytic Wet Air Oxidation

Di-Nitrophenol

Denitrification Baffled Reactor

Fluidized Bed Bioreactor

Fluidized Bed Bioreactor

Fixed Film Reactor

Fischer-Tropsch

Granular Activated Sludge

Gas-to-liquid

Hydrocarbons

Hydraulic Retention Time

Integrated Anaerobic Fluidized Bed Bioreactor

Long Chain Alcohol

Modified Anaerobic Sequential Batch Reactor

Micro-electrolysis Cell

Magnetic Nanoparticles

Non-acid oxygenated

Organic Carbon

Oxidation-reduction Potential

Rotating Biological Contactor

Packed Bed Reactor

Polyurethane Foam

Polyvinyl alcohol

Spouted Bed Bioreactor

Short Chain Alcohol

Sulpher Reducing Bacteria

Trichloroethylene

Total Dissolved Solids

Total Organic Carbon

Petroleum Hydrocarbon

Tricking Packed-Bed Reactors 
TSS

UASB

USR

VFA

ZVI
Total Suspended Solids

Upflow Anaerobic Sludge Reactors

Up-flow Anaerobic Solid Reactor

Volatile Fatty Acids

Zero Valent Iron

\section{References}

1. Wang, W.; Han, H.; Yuan, M.; Li, H. Enhanced anaerobic biodegradability of real coal gasification wastewater with methanol addition. J. Environ. Sci. 2010, 22, 1868-1874. [CrossRef]

2. Zhang, M.; Tay, J.H.; Qian, Y.; Gu, X.S. Coke plant wastewater treatment by fixed biofilm system for COD and NH3-N removal. Water Res. 1998, 32, 519-527. [CrossRef]

3. Sirtori, C.; Zapata, A.; Oller, I.; Gernjak, W.; Agüera, A.; Malato, S. Decontamination industrial pharmaceutical wastewater by combining solar photo-Fenton and biological treatment. Water Res. 2009, 43, 661-668. [CrossRef] [PubMed]

4. Kurniawan, T.A.; Chan, G.Y.S.; Lo, W.H.; Babel, S. Physico-chemical treatment techniques for wastewater laden with heavy metals. Chem. Eng. J. 2006, 118, 83-98. [CrossRef]

5. Damjanović, L.; Rakić, V.; Rac, V.; Stošić, D.; Auroux, A. The investigation of phenol removal from aqueous solutions by zeolites as solid adsorbents. J. Hazard. Mater. 2010, 184, 477-484. [CrossRef]

6. Al-Khalid, T.; El-Naas, M.H. Aerobic biodegradation of phenols: A comprehensive review. Crit. Rev. Environ. Sci. Technol. 2012, 42, 1631-1690. [CrossRef]

7. Gao, D.W.; Hu, Q.; Yao, C.; Ren, N.Q. Treatment of domestic wastewater by an integrated anaerobic fluidized-bed membrane bioreactor under moderate to low temperature conditions. Bioresour. Technol. 2014, 159, 193-198. [CrossRef]

8. Mujtaba, G.; Rizwan, M.; Kim, G.; Lee, K. Removal of nutrients and COD through co-culturing activated sludge and immobilized Chlorella vulgaris. Chem. Eng. J. 2018, 343, 155-162. [CrossRef]

9. Tziotzios, G.; Teliou, M.; Kaltsouni, V.; Lyberatos, G.; Vayenas, D.V. Biological phenol removal using suspended growth and packed bed reactors. Biochem. Eng. J. 2005, 26, 65-71. [CrossRef]

10. Ettayebi, K.; Errachidi, F.; Jamai, L.; Tahri-Jouti, M.A.; Sendide, K.; Ettayebi, M. Biodegradation of polyphenols with immobilized Candida tropicalis under metabolic induction. FEMS Microbiol. Lett. 2003, 223, 215-219. [CrossRef]

11. El-Naas, M.H.; Mourad, A.H.I.; Surkatti, R. Evaluation of the characteristics of polyvinyl alcohol (PVA) as matrices for the immobilization of Pseudomonas putida. Int. Biodeterior. Biodegrad. 2013, 85, 413-420. [CrossRef]

12. Mukherjee, P.; Ahmad, A.; Mandal, D.; Senapati, S.; Sainkar, S.R.; Khan, M.I.; Parishcha, R.; Ajaykumar, P.V.; Alam, M.; Kumar, R.; et al. Fungus-Mediated Synthesis of Silver Nanoparticles and Their Immobilization in the Mycelial Matrix : A Novel Biological Approach to Nanoparticle. Nano Lett. 2001, 1, 515-519. [CrossRef]

13. Schrinner, M.; Proch, S.; Mei, Y.; Kempe, R.; Miyajima, N.; Ballauff, M. Stable bimetallic gold-platinum nanoparticles immobilized on spherical polyelectrolyte brushes: Synthesis, characterization, and application for the oxidation of alcohols. Adv. Mater. 2008, 20, 1928-1933. [CrossRef]

14. Fan, J.; Chen, D.; Li, N.; Xu, Q.; Li, H.; He, J.; Lu, J. Adsorption and biodegradation of dye in wastewater with Fe3O4@MIL-100 (Fe) core-shell bio-nanocomposites. Chemosphere 2018, 191, 315-323. [CrossRef]

15. Enyi, G.; Nasr, G.; Burby, M. Economics of wastewater treatment in GTL plant using spray technique. Int. J. Energy Environ. 2013, 2, 571-582.

16. Wang, D.; Ma, W.; Han, H.; Li, K.; Hao, X. Enhanced treatment of Fischer-Tropsch (F-T) wastewater by novel anaerobic biofilm system with scrap zero valent iron (SZVI) assisted. Biochem. Eng. J. 2017, 117, 66-76. [CrossRef]

17. Wang, D.; Han, H.; Han, Y.; Li, K.; Zhu, H. Enhanced treatment of Fischer-Tropsch (F-T) wastewater using the up-flow anaerobic sludge blanket coupled with bioelectrochemical system: Effect of electric field. Bioresour. Technol. 2017, 232, 18-26. [CrossRef]

18. Müller, N.; Worm, P.; Schink, B.; Stams, A.J.M.; Plugge, C.M. Syntrophic butyrate and propionate oxidation processes: From genomes to reaction mechanisms. Environ. Microbiol. Rep. 2010, 2, 489-499. [CrossRef] 
19. El-Naas, M.H.; Al-Zuhair, S.; Alhaija, M.A. Removal of phenol from petroleum refinery wastewater through adsorption on date-pit activated carbon. Chem. Eng. J. 2010, 162, 997-1005. [CrossRef]

20. Sonune, A.; Ghate, R. Developments in wastewater treatment methods. Desalination 2004, 167, 55-63. [CrossRef]

21. El-Naas, M.H.; Surkatti, R.; Al-Zuhair, S. Petroleum refinery wastewater treatment: A pilot scale study. J. Water Process Eng. 2016, 14, 71-76. [CrossRef]

22. Wang, W.; Han, H. Recovery strategies for tackling the impact of phenolic compounds in a UASB reactor treating coal gasification wastewater. Bioresour. Technol. 2012, 103, 95-100. [CrossRef]

23. Paździor, K.; Wrębiak, J.; Klepacz-Smółka, A.; Gmurek, M.; Bilińska, L.; Kos, L.; Sójka-Ledakowicz, J.; Ledakowicz, S. Influence of ozonation and biodegradation on toxicity of industrial textile wastewater. J. Environ. Manag. 2017, 195, 166-173. [CrossRef] [PubMed]

24. Fadil, K.; Chahlaoui, A.; Ouahbi, A.; Zaid, A.; Borja, R. Aerobic biodegradation and detoxification of wastewaters from the olive oil industry. Int. Biodeterior. Biodegrad. 2003, 51,37-41. [CrossRef]

25. Vijayaraghavan, K.; Ahmad, D.; Aziz, M.E.B.A. Aerobic treatment of palm oil mill effluent. J. Environ. Manag. 2007, 82, 24-31. [CrossRef]

26. Miladinovic, N.; Weatherley, L.R. Intensification of ammonia removal in a combined ion-exchange and nitrification column. Chem. Eng. J. 2008, 135, 15-24. [CrossRef]

27. Ghigliazza, R.; Lodi, A.; Rovatti, M. Kinetic and process considerations on biological reduction of soluble and scarcely soluble sulfates. Resour. Conserv. Recycl. 2000, 29, 181-194. [CrossRef]

28. Zacharia, R.; El-naas, M.H. Photocatalytic Oxidation of Non-Acid Oxygenated Hydrocarbons. Water Manag. 2004, 287-303. [CrossRef]

29. Hao, O.; Kim, H.; Chiang, P.-C. Decolorization of Wastewater. Crit. Rev. Environ. Sci. Technol. 2000, 30, 1-6. [CrossRef]

30. Candia-onfray, C.; Espinoza, N.; Sabino, E.B.; Salazar, R. Treatment of winery wastewater by anodic oxidation using BDD electrode. Chemosphere 2018, 206, 709-717. [CrossRef]

31. Rodrigues, C.R.; Benvenuti, T.; Trindade, C.D.M.D.; Pereira, M.A.F.; Zoppas-Ferreira, J.; Pérez-Herranz, V.; Bernardes, A.M.; Rodrigues, G.C.; Tatiane, B.; De Moraes, D.T.C.; et al. Electrodialysis for the tertiary treatment of municipal wastewater : Efficiency of ion removal and ageing of ion exchange membranes. J. Environ. Chem. Eng. 2018, 6, 5855-5869.

32. El-Naas, M.H.; Al-Zuhair, S.; Al-Lobaney, A.; Makhlouf, S. Assessment of electrocoagulation for the treatment of petroleum refinery wastewater. J. Environ. Manag. 2009, 91, 180-185. [CrossRef] [PubMed]

33. Giray, S.; Hakan, M.; Akarsu, S. Comparison of classic Fenton with ultrasound Fenton processes on industrial textile wastewater. Sustain. Environ. Res. 2018, 28, 165-170.

34. Campos, J.C.; Borges, R.M.H.; Filho, A.M.O.; Nobrega, R.; Sant'Anna, G.L. Oilfield wastewater treatment by combined microfiltration and biological processes. Water Res. 2002, 36, 95-104. [CrossRef]

35. Mazzeo, D.E.C.; Levy, C.E.; de Angelis, D.d.F.; Marin-Morales, M.A. BTEX biodegradation by bacteria from effluents of petroleum refinery. Sci. Total Environ. 2010, 408, 4334-4340. [CrossRef]

36. Shimizu, Y.; Uryu, K.; Okuno, Y.I.; Watanabe, A. Cross-flow microfiltration of activated sludge using submerged membrane with air bubbling. J. Ferment. Bioeng. 1996, 81, 55-60. [CrossRef]

37. Gebara, F. Activated sludge bioilm wastewater treatment system. Water Res. 1999, 33, 230-238. [CrossRef]

38. El-Naas, M.H.; Al-Zuhair, S.; Makhlouf, S. Continuous biodegradation of phenol in a spouted bed bioreactor (SBBR). Chem. Eng. J. 2010, 160, 565-570. [CrossRef]

39. Tchobanoglous, G.; Burton, F.L.; Stensel, H.D. Wastewater Engineering: Treatment and Reuse. AWWA 2013, 95, 201.

40. Lema, J.M.; Mendez, R.; Blazquez, R. Characteristics of landfill leachates and alternatives for their treatment: A review. Water. Air. Soil Pollut. 1988, 40, 223-250.

41. Chan, Y.J.; Chong, M.F.; Law, C.L.; Hassell, D.G. A review on anaerobic-aerobic treatment of industrial and municipal wastewater. Chem. Eng. J. 2009, 155, 1-18. [CrossRef]

42. Feng, Y.; Zhang, Y.; Chen, S.; Quan, X. Enhanced production of methane from waste activated sludge by the combination of high-solid anaerobic digestion and microbial electrolysis cell with iron-graphite electrode. Chem. Eng. J. 2015, 259, 787-794. [CrossRef] 
43. Vázquez, I.; Rodríguez, J.; Marañón, E.; Castrillón, L.; Fernández, Y. Simultaneous removal of phenol, ammonium and thiocyanate from coke wastewater by aerobic biodegradation. J. Hazard. Mater. 2006, 137, 1773-1780. [CrossRef] [PubMed]

44. Shokrollahzadeh, S.; Azizmohseni, F.; Golmohammad, F.; Shokouhi, H.; Khademhaghighat, F. Biodegradation potential and bacterial diversity of a petrochemical wastewater treatment plant in Iran. Bioresour. Technol. 2008, 99, 6127-6133. [CrossRef] [PubMed]

45. Chavan, A.; Mukherji, S. Treatment of hydrocarbon-rich wastewater using oil degrading bacteria and phototrophic microorganisms in rotating biological contactor: Effect of N:P ratio. J. Hazard. Mater. 2008, 154, 63-72. [CrossRef]

46. Yan, J.; Jianping, W.; Jing, B.; Daoquan, W.; Zongding, H. Phenol biodegradation by the yeast Candida tropicalis in the presence of m-cresol. Biochem. Eng. J. 2006, 29, 227-234. [CrossRef]

47. Mujtaba, G.; Rizwan, M.; Lee, K. Removal of nutrients and COD from wastewater using symbiotic co-culture of bacterium Pseudomonas putida and immobilized microalga Chlorella vulgaris. J. Ind. Eng. Chem. 2017, 49, 145-151. [CrossRef]

48. Kumar, A.; Kumar, S.; Kumar, S. Biodegradation kinetics of phenol and catechol using Pseudomonas putida MTCC 1194. Biochem. Eng. J. 2005, 22, 151-159. [CrossRef]

49. González, G.; Herrera, G.; García, M.T.; Peña, M. Biodegradation of phenolic industrial wastewater in a fluidized bed bioreactor with immobilized cells of Pseudomonas putida. Bioresour. Technol. 2001, 80, 137-142. [CrossRef]

50. Sá, C.S.A.; Boaventura, R.A.R. Biodegradation of phenol by Pseudomonas putida DSM 548 in a trickling bed reactor. Biochem. Eng. J. 2001, 9, 211-219. [CrossRef]

51. El-Naas, M.H.; Al-Muhtaseb, S.A.; Makhlouf, S. Biodegradation of phenol by Pseudomonas putida immobilized in polyvinyl alcohol (PVA) gel. J. Hazard. Mater. 2009, 164, 720-725. [CrossRef] [PubMed]

52. Afzal, M.; Iqbal, S.; Rauf, S.; Khalid, Z.M. Characteristics of phenol biodegradation in saline solutions by monocultures of Pseudomonas aeruginosa and Pseudomonas pseudomallei. J. Hazard. Mater. 2007, 149, 60-66. [CrossRef] [PubMed]

53. Pourbabaee, A.A.; Malekzadeh, F.; Sarbolouki, M.N.; Najafi, F. Aerobic decolorization and detoxification of a disperse dye in textile effluent by a new isolate of Bacillus sp. Biotechnol. Bioeng. 2006, 93, 631-635. [CrossRef]

54. Banerjee, A.; Ghoshal, A.K. Biodegradation of an actual petroleum wastewater in a packed bed reactor by an immobilized biomass of Bacillus cereus. J. Environ. Chem. Eng. 2017, 5, 1696-1702. [CrossRef]

55. Mahdavianpour, M.; Moussavi, G.; Farrokhi, M. Biodegradation and COD removal of p-Cresol in a denitrification baffled reactor: Performance evaluation and microbial community. Process Biochem. 2018, 69, 153-160. [CrossRef]

56. Qi, W.; Mei, S.; Yuan, Y.; Li, X.; Tang, T.; Zhao, Q. Enhancing fermentation wastewater treatment by co-culture of microalgae with volatile fatty acid- and alcohol-degrading bacteria. Algal Res. 2018, 31, 31-39. [CrossRef]

57. Gonçalves, C.; Lopes, M.; Ferreira, J.P.; Belo, I. Bioresource Technology Biological treatment of olive mill wastewater by non-conventional yeasts. Bioresour. Technol. 2009, 100, 3759-3763. [CrossRef]

58. Chtourou, M.; Ammar, E.; Nasri, M.; Medhioub, K. Isolation of a yeast, Trichosporon cutaneum, able to use low molecular weight phenolic compounds: Applcation to olive mill waste water treatment. J. Chem. Technol. Biotechnol. 2004, 76, 869-878. [CrossRef]

59. Lu, Y.; Yan, L.; Wang, Y.; Zhou, S.; Fu, J.; Zhang, J. Biodegradation of phenolic compounds from coking wastewater by immobilized white rot fungus Phanerochaete chrysosporium. J. Hazard. Mater. 2009, 165, 1091-1097. [CrossRef]

60. Surkatti, R.; Al-Zuhair, S. Effect of cresols treatment by microalgae on the cells' composition. J. Water Process Eng. 2018, 26, 250-256. [CrossRef]

61. Klekner, V.; Kosaric, N. Degradation of phenols by algae. Environ. Technol. 1992, 13, 493-501. [CrossRef]

62. Das, B.; Mandal, T.K.; Patra, S. A comprehensive study on Chlorella pyrenoidosa for phenol degradation and its potential applicability as biodiesel feedstock and animal feed. Appl. Biochem. Biotechnol. 2015, 176, 1382-1401. [CrossRef] [PubMed]

63. di Caprio, F.; Altimari, P.; Pagnanelli, F. Integrated biomass production and biodegradation of olive mill wastewater by cultivation of Scenedesmus sp. Algal Res. 2015, 9, 306-311. [CrossRef] 
64. Papazi, A.; Assimakopoulos, K.; Kotzabasis, K. Bioenergetic Strategy for the Biodegradation of p-Cresol by the Unicellular Green Alga Scenedesmus obliquus. PLoS ONE 2012, 7, e51852. [CrossRef] [PubMed]

65. Hesnawi, R.; Dahmani, K.; Al-Swayah, A.; Mohamed, S.; Mohammed, S.A. Biodegradation of municipal wastewater with local and commercial bacteria. Procedia Eng. 2014, 70, 810-814. [CrossRef]

66. Fountoulakis, M.S.; Dokianakis, S.N.; Kornaros, M.E.; Aggelis, G.G.; Lyberatos, G. Removal of phenolics in olive mill wastewaters using the white-rot fungus Pleurotus ostreatus. Water Res. 2002, 36, 4735-4744. [CrossRef]

67. Al-Zuhair, S.; Nabil, M.; Abdi, Y.; al Sayyed, M.; Taher, H. High Concentration Phenol Removal Using Freshwater Microalgae. Int. J. Biotechnol. Wellness Ind. 2016, 5, 39-45. [CrossRef]

68. Muñoz, R.; Guieysse, B. Algal-bacterial processes for the treatment of hazardous contaminants: A review. Water Res. 2006, 40, 2799-2815. [CrossRef]

69. Rajeshwari, K.; Balakrishnan, M.; Kansal, A.; Lata, K.; Kishore, V.V. State-of-the-art of anaerobic digestion technology for industrial wastewater treatment. Renew. Sustain. Energy Rev. 2000, 4, 135-156. [CrossRef]

70. Lettinga, G. Anaerobic digestion and wastewater treatment systems. Antonie Van Leeuwenhoek 1995, 67, 3-28. [CrossRef]

71. Zhen, G.; Lu, X.; Kobayashi, T.; Su, L.; Kumar, G.; Bakonyi, P.; He, Y.; Sivagurunathan, P.; Nemestóthy, N.; $\mathrm{Xu}, \mathrm{K}$. -Q.; et al. Continuous micro-current stimulation to upgrade methanolic wastewater biodegradation and biomethane recovery in an upflow anaerobic sludge blanket (UASB) reactor. Chemosphere 2017, 180, 229-238. [CrossRef] [PubMed]

72. Rastegar, S.O.; Mousavi, S.M.; Shojaosadati, S.A.; Sheibani, S. Optimization of petroleum refinery effluent treatment in a UASB reactor using response surface methodology. J. Hazard. Mater. 2011, 197, $26-32$. [CrossRef] [PubMed]

73. Zhou, G.M.; Fang, H.H.P. Co-degradatiion of phenol and $\mathrm{m}$-cresol in a UASB reactor. Bioresour. Technol. 1997, 61, 47-52. [CrossRef]

74. Surkatti, R.; El-Naas, M.H. Biological treatment of wastewater contaminated with p-cresol using Pseudomonas putida immobilized in polyvinyl alcohol (PVA) gel. J. Water Process Eng. 2014, 1, 84-90. [CrossRef]

75. Gao, D.-W.; Zhang, T.; Tang, C.-Y.Y.; Wu, W.-M.; Wong, C.-Y.; Lee, Y.H.; Yeh, D.H.; Criddle, C.S. Membrane fouling in an anaerobic membrane bioreactor: Differences in relative abundance of bacterial species in the membrane foulant layer and in suspension. J. Membr. Sci. 2010, 364, 331-338. [CrossRef]

76. Monsalvo, V.M.; McDonald, J.A.; Khan, S.J.; Le-Clech, P. Removal of trace organics by anaerobic membrane bioreactors. Water Res. 2014, 49, 103-112. [CrossRef]

77. Rajasimman, M.; Babu, S.V.; Rajamohan, N. Biodegradation of textile dyeing industry wastewater using modified anaerobic sequential batch reactor-Start-up, parameter optimization and performance analysis. J. Taiwan Inst. Chem. Eng. 2017, 72, 171-181. [CrossRef]

78. Li, B.; Sun, Y.; Li, Y. Pretreatment of coking wastewater using anaerobic sequencing batch reactor (ASBR). J. Zhejiang Univ. Sci. B 2005, 6, 1115-1123. [CrossRef]

79. Derakhshan, Z.; Mahvi, A.H.; Ghaneian, M.T.; Mazloomi, S.M.; Faramarzian, M.; Dehghani, M.; Fallahzadeh, H.; Yousefinejad, S.; Berizi, E.; Ehrampoush, M.H.; et al. Simultaneous removal of atrazine and organic matter from wastewater using anaerobic moving bed biofilm reactor: A performance analysis. J. Environ. Manag. 2018, 209, 515-524. [CrossRef]

80. Shao, X.; Peng, D.; Teng, Z.; Ju, X. Treatment of brewery wastewater using anaerobic sequencing batch reactor (ASBR). Bioresour. Technol. 2008, 99, 3182-3186. [CrossRef]

81. Landbouwcatalogus, C. The Anaerobic Treatment of Low Strength Soluble Wastewaters. Available online: https://edepot.wur.nl/206966 (accessed on 25 July 2020).

82. Pen, B.; Cuauhna, P. Anaerobic treatment of organic chemical wastewater using packed bed reactors. Water Sci. Technol. 2006, 54, 67-77.

83. Monroy, O.; Meraz, M. Treatment of a low concentration industrial chemicals mixture in an UASB reactor. Water Sci. Technol. 1996, 52, 385-390.

84. Han, S.; Kim, S.; Shin, H. UASB treatment of wastewater with VFA and alcohol generated during hydrogen fermentation of food waste. Process. Biochem. 2005, 40, 2897-2905. [CrossRef] 
85. Jianguang, L.I.U.; Chunyang, Z.; Guanglan, Z.; Hainan, G.A.N. Reclaiming Bioenergy From Alcohol Wastewater by Upflow Anaerobic Solid Reactor Process and High Value Use of Biogas. In Proceedings of the 2011 International Conference on New Technology of Agricultural, Zibo, China, 27-29 May 2011; pp. 537-539.

86. Flaherty, V.O.; Colleran, E. Effect of sulphate addition on volatile fatty acid and ethanol degradation in an anaerobic hybrid reactor I: Process disturbance and remediation. Bioresour. Technol. 1999, 68, 101-107. [CrossRef]

87. Intanoo, P.; Rangsunvigit, P.; Namprohm, W. Hydrogen production from alcohol wastewater by an anaerobic sequencing batch reactor under thermophilic operation: Nitrogen and phosphorous uptakes and transformation. Int. J. Hydrogen Energy 2012, 37, 11104-11112. [CrossRef]

88. Henry, M.P.; Donlon, B.A.; Lens, P.N.; Colleran, E.M. Use of Anaerobic Hybrid Reactors for Treatment of Synthetic Pharmaceutical Wastewaters Containing Organic Solvents. J. Chem. Technol. Biotechnol. 1996, 66, 251-264. [CrossRef]

89. Carlsen, N. Effects of alcohols on the respiration and fermentation of aerated suspensions of baker's yeast. J. Gen. Microbiol. 2019, 137, 2879-2883. [CrossRef]

90. Sengar, A.; Basheer, F.; Aziz, A.; Farooqi, I.H. Aerobic granulation technology : Laboratory studies to full scale practices. J. Clean. Prod. 2018, 197, 616-632. [CrossRef]

91. Takeno, K.; Yamaoka, Y.; Sasaki, K. Treatment of oil-containing sewage- wastewater using immobilized photo-synthetic bacteria. World J. Microbiol. Biotechnol. 2005, 21, 1385-1391. [CrossRef]

92. Ehlers, G.A.; Rose, P.D. Immobilized white-rot fungal biodegradation of phenol and chlorinated phenol in trickling packed-bed reactors by employing sequencing batch operation. Bioresour. Technol. 2005, 96, 1264-1275. [CrossRef]

93. Khan, M.Z.; Mondal, P.K.; Sabir, S. Aerobic granulation for wastewater bioremediation: A review. Can. J. Chem. Eng. 2013, 91, 1045-1058. [CrossRef]

94. Vashi, H.; Iorhemen, O.T.; Tay, J.H. Aerobic granulation: A recent development on the biological treatment of pulp and paper wastewater. Environ. Technol. Innov. 2018, 9, 265-274. [CrossRef]

95. Prieto, M.B.; Hidalgo, A.; Rodríguez-Fernández, C.; Serra, J.L.; Llama, M.J. Biodegradation of phenol in synthetic and industrial wastewater by Rhodococcus erythropolis UPV-1 immobilized in an air-stirred reactor with clarifier. Appl. Microbiol. Biotechnol. 2002, 58, 853-859. [PubMed]

96. Jiang, L.; Ruan, Q.; Li, R.; Li, T. Biodegradation of phenol by using free and immobilized cells of Acinetobacter sp. BS8Y. J. Basic Microbiol. 2013, 53, 224-230. [CrossRef]

97. Ismail, Z.Z.; Khudhair, H.A. Biotreatment of real petroleum wastewater using non-acclimated immobilized mixed cells in spouted bed bioreactor. Biochem. Eng. J. 2018, 131, 17-23. [CrossRef]

98. Tam, N.F.Y.; Wong, Y.S. Effect of immobilized microalgal bead concentrations on wastewater nutrient removal. Environ. Pollut. 2000, 107, 145-151. [CrossRef]

99. Liu, Y.J.; Zhang, A.N.; Wang, X.C. Biodegradation of phenol by using free and immobilized cells of Acinetobacter sp. XA05 and Sphingomonas sp. FG03. Biochem. Eng. J. 2009, 44, 187-192. [CrossRef]

100. Wang, L.; Huang, L.-J.; Yun, L.-J.; Tang, F.; Zhao, J.-H.; Liu, Y.-Q.; Zeng, X.; Luo, Q.-F. Removal of nitrogen, phosphorus, and organic pollutants from water using seeding type immobilized microorganisms. Biomed. Environ. Sci. 2008, 21, 150-156. [CrossRef]

101. Wang, J.; Yang, H.; Lu, H.; Zhou, J.; Zheng, C. Aerobic biodegradation of nitrobenzene by a defined microbial consortium immobilized in polyurethane foam. World J. Microbiol. Biotechnol. 2009, 25, 875-881. [CrossRef]

102. Jiang, H.L.; Tay, J.H.; Tay, S.T.L. Aggregation of immobilized activated sludge cells into aerobically grown microbial granules for the aerobic biodegradation of phenol. Lett. Appl. Microbiol. 2002, 35, 439-445. [CrossRef]

103. Ni, B.; Xie, W.-M.; Liu, S.-G.; Yu, H.-Q.; Wang, Y.-Z.; Wang, G.; Dai, X.-L. Granulation of activated sludge in a pilot-scale sequencing batch reactor for the treatment of low-strength municipal wastewater. Water Res. 2009, 43, 751-761. [CrossRef]

104. Muda, K.; Aris, A.; Salim, M.R.; Ibrahim, Z.; Yahya, A.; Van Loosdrecht, M.C.M.; Ahmad, A.; Nawahwi, M.Z. Development of granular sludge for textile wastewater treatment. Water Res. 2010, 44, 4341-4350. [CrossRef] [PubMed]

105. Şen, S.; Demirer, G.N. Anaerobic treatment of real textile wastewater with a fluidized bed reactor. Water Res. 2003, 37, 1868-1878. [CrossRef] 
106. Haribabu, K.; Sivasubramanian, V. Treatment of wastewater in fluidized bed bioreactor using low density biosupport. Energy Procedia 2014, 50, 214-221. [CrossRef]

107. Dyal, A.; Loos, K.; Noto, M.; Chang, S.W.; Spagnoli, C.; Shafi, K.V.P.M.; Ulman, A.; Cowman, M.; Gross, R.A. Activity of Candida rugosa Lipase Immobilized on $\gamma$-Fe2O3 Magnetic Nanoparticles. J. Am. Chem. Soc. 2003, 125, 1684-1685. [CrossRef] [PubMed]

108. Yong, Y.; Bai, Y.; Li, Y.; Lin, L.; Cui, Y.; Xia, C. Preparation and application of polymer-grafted magnetic nanoparticles for lipase immobilization. J. Magn. Magn. Mater. 2008, 320, 2350-2355. [CrossRef]

109. Peng, Q.; Liu, Y.; Zeng, G.; Xu, W.; Yang, C.; Zhang, J. Biosorption of copper(II) by immobilizing Saccharomyces cerevisiae on the surface of chitosan-coated magnetic nanoparticles from aqueous solution. J. Hazard. Mater. 2010, 177, 676-682. [CrossRef]

110. Li, H.; Li, Z.; Liu, T.; Xiao, X.; Peng, Z.; Deng, L. A novel technology for biosorption and recovery hexavalent chromium in wastewater by bio-functional magnetic beads. Bioresour. Technol. 2008, 99, 6271-6279. [CrossRef]

111. Xu, P.; Zeng, G.; Huang, D.; Hu, S.; Feng, C. Colloids and Surfaces A: Physicochemical and Engineering Aspects Synthesis of iron oxide nanoparticles and their application in Phanerochaete chrysosporium immobilization for $\mathrm{Pb}$ (II) removal. Colloids Surfaces A Physicochem. Eng. Asp. 2013, 419, 147-155. [CrossRef]

112. Zhou, L.; Li, G.; An, T. Synthesis and characterization of novel magnetic Fe3O4/polyurethane foam composite applied to the carrier of immobilized microorganisms for wastewater treatment. Res. Chem. Intermed. 2010, 36, 277-288. [CrossRef]

113. Majone, M.; Aulenta, F.; Dionisi, D.; D’Addario, E.N.; Sbardellati, R.; Bolzonella, D.; Beccari, M. High-rate anaerobic treatment of Fischer-Tropsch wastewater in a packed-bed biofilm reactor. Water Res. 2010, 44, 2745-2752. [CrossRef] [PubMed]

114. Bao, B.; El-Halwagi, M.M.; Elbashir, N.O. Simulation, integration, and economic analysis of gas-to-liquid processes. Fuel Process. Technol. 2010, 91, 703-713. [CrossRef]

115. Kim, Y.H.; Jun, K.W.; Joo, H.; Han, C.; Song, I.K. A simulation study on gas-to-liquid (natural gas to Fischer-Tropsch synthetic fuel) process optimization. Chem. Eng. J. 2009, 155, 427-432. [CrossRef]

116. Knottenbelt, C. Mossgas 'gas-to-liquid' diesel fuels-An environmentally friendly option. Catal. Today 2002, 71, 437-445. [CrossRef]

117. Onwusogh, U. Feasibility of Produced Water Treatment and Reuse-Case Study of a GTL. In Proceedings of the International Petroleum Technology Conference, Doha, Qatar, 6-9 December 2015.

118. Saravanan, N.P.; van Vuuren, M.J. Process Wastewater Treatment and Management in Gas-to-Liquids Industries. SPE Oil Gas India Conf. Exhib. 2010, 20-22. [CrossRef]

119. Dores, R.; Hussain, A.; Katebah, M.; Adham, S.; Global, C.; Sustainability, W. Using Advanced Water Treatment Technologies To Treat Produced Water From The Petroleum Industry. In Proceedings of the SPE International Production and Operations Conference \& Exhibition, Doha, Qatar, 14-16 May 2012.

120. Maitlis, P.M.; Klerk, D. Greener Fischer-Tropsch Processes for Fuels and Feedstocks; Wiley-VCH: Weinheim, Germany, 2011.

121. Chen, Y.; Cheng, J.J.; Creamer, K.S. Inhibition of anaerobic digestion process: A review. Bioresour. Technol. 2008, 99, 4044-4064. [CrossRef] [PubMed]

122. Wang, D.; Han, Y.; Han, H.; Li, K.; Xu, C. Enhanced treatment of Fischer-Tropsch wastewater using up-flow anaerobic sludge blanket system coupled with micro-electrolysis cell: A pilot scale study. Bioresour. Technol. 2017, 238, 333-342. [CrossRef] [PubMed]

123. Wang, D.; Ma, W.; Han, H.; Li, K.; Xu, H.; Fang, F.; Hou, B.; Jia, S. Enhanced anaerobic degradation of Fischer-Tropsch wastewater by integrated UASB system with Fe-C micro-electrolysis assisted. Chemosphere 2016, 164, 14-24. [CrossRef]

(C) 2020 by the authors. Licensee MDPI, Basel, Switzerland. This article is an open access article distributed under the terms and conditions of the Creative Commons Attribution (CC BY) license (http://creativecommons.org/licenses/by/4.0/). 